\title{
العنف المدرسي لدى تلاميذ مرحلة التعليم المتوسط \\ ودور الأخصائي النفسي في التخفيف منه \\ دراسة ميدانية بمتوسطات ولاية تيزي وزو، الجزائر
}

الدكتور : محمد برو، جامعة المسيلة، الجزائر

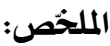

هدفت هذه الدراسة إلى معرفة ظاهرة العنف المدرسي، هذه الظاهرة الخطيرة التي

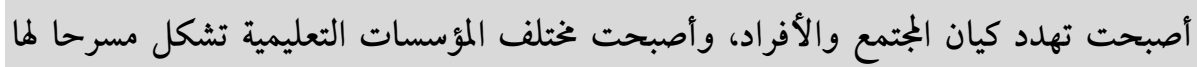
من خلال أعمال العنف والتخريب والترهيب... ما جعل الكل يراجع حساباته لما تتركه من خسائر مادية ومعنوية، فضلا عن تكلفتها النفسية والاجتماعية التي يعاني منها الإداريون والأساتذة وأولياء الأمور والتلاميذ أنفسهم، ومما يبين خطورتها عدد المشتكين من التلاميذ

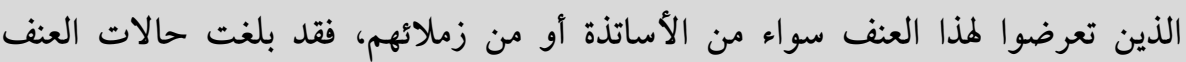
المدرسي على سبيل المثال فقط سنة 2000، 2762 حالة منها 19 كانت قاتلة.

\section{Résumé:}

Le but de cette étude est d'étudier le phénomène de la violence scolaire, ce phénomène dangereux qui est devenu une entité menaçante pour la société et les individus. Les divers établissements d'enseignement constituent aujourd'hui, le théâtre de la violence, du vandalisme et de l'intimidation... cela, fait appel à chacun de nous, vu les pertes morales et matérielles que peut engendrer cette violence, ainsi que les coûts psychologiques et sociaux dont souffrent les administrateurs, les enseignants, les parents et les élèves. Ce qui montre la gravité de ce phénomène, le nombre d'élèves plaignants qui ont été exposés à la violence des professeurs ou des camarades de classe .A titre d'exemple, les cas de violence à l'école, ont atteint dans l'année 2000, 2762 cas, dont 19 mortels. 


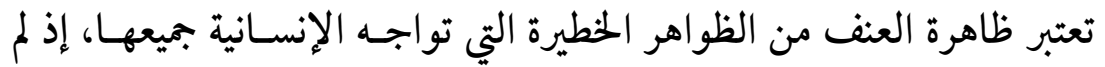

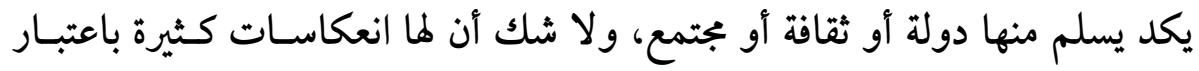

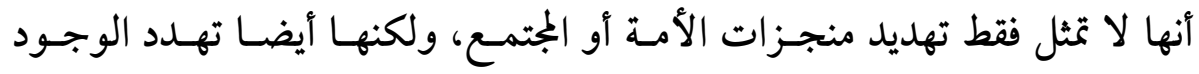

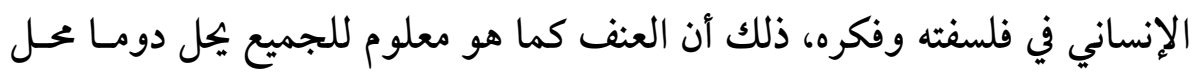

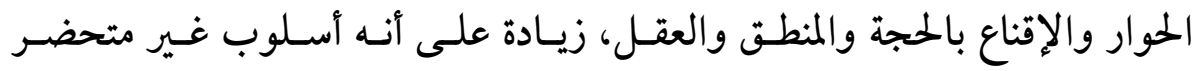

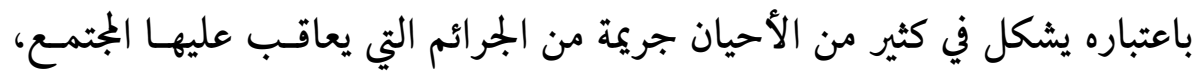

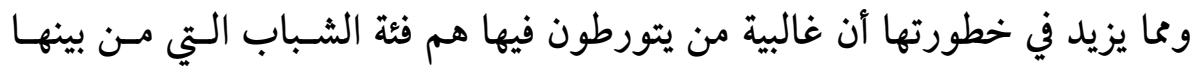

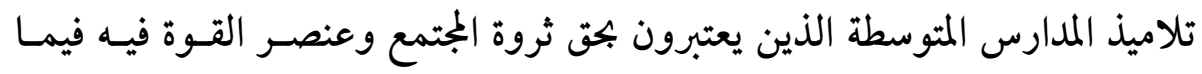

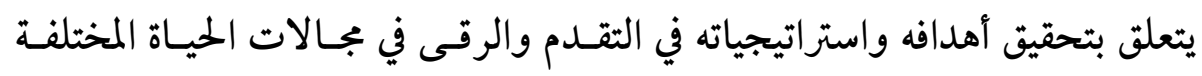
مستقبلا.

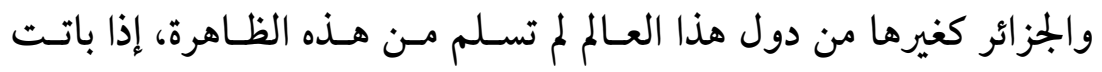

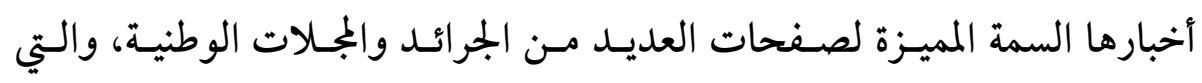

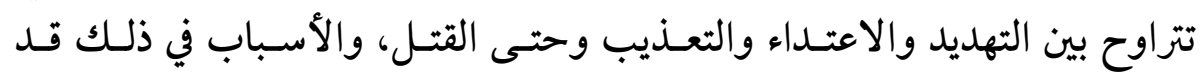

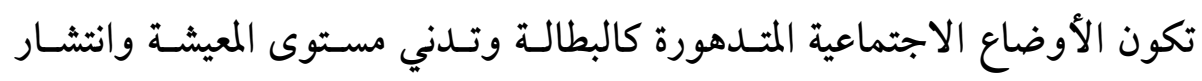
الآفات الاجتماعية كالإدمان والتفكك الأسري....

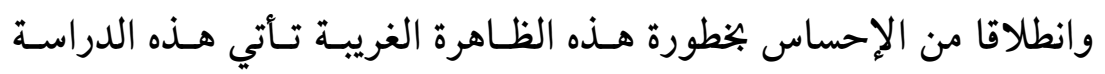

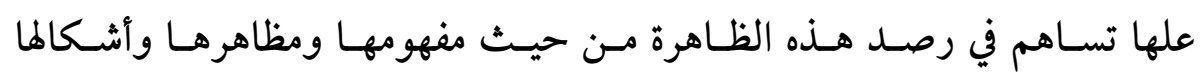

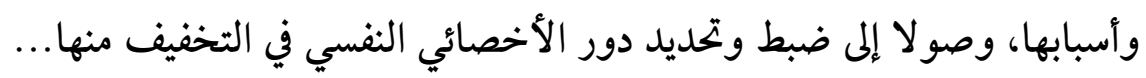

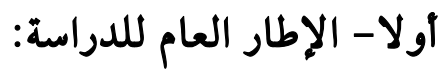
1- الملفية النظرية للدراسة:

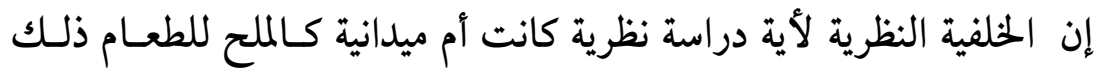

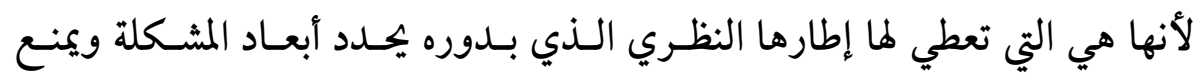

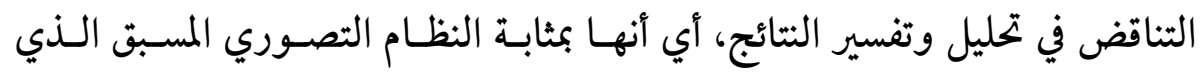


يعمل كأساس لاختيار وتنظيم وإعطاء الحقائق دلالتها والنتائج ملاءمتها وعلميتها

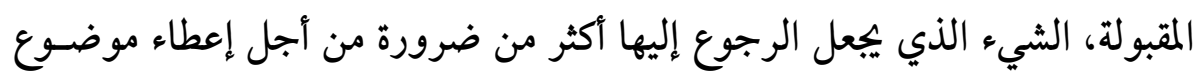

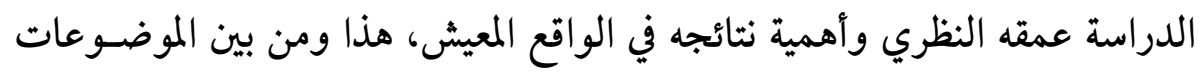

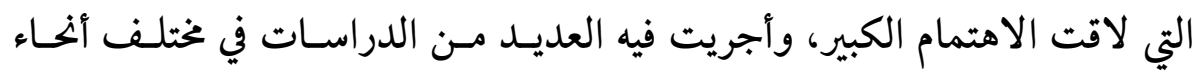

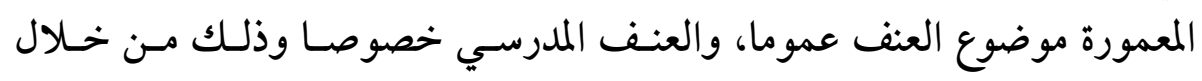

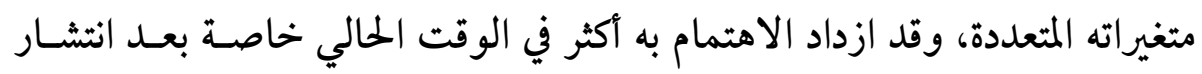

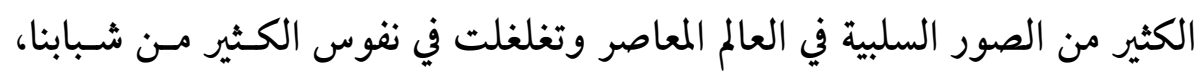

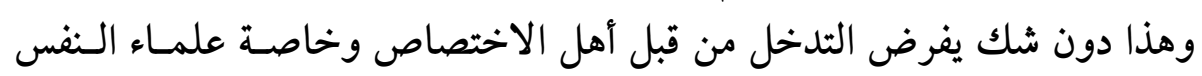

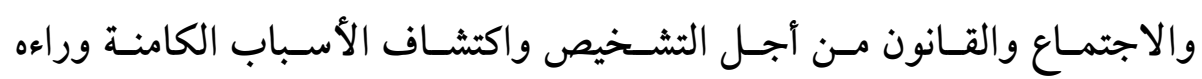
وتقديم مقترحات لتجاوزه.

وفي هذا الإطار جاءت العديد من الدراسات هدفها الأول والأخير فهم

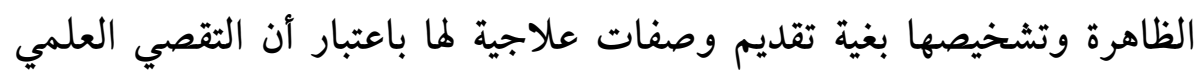
الجاد لتحديد ورصد أسباب وعوامل هذا العنف يعود على المجتمع باستخدام أمثل

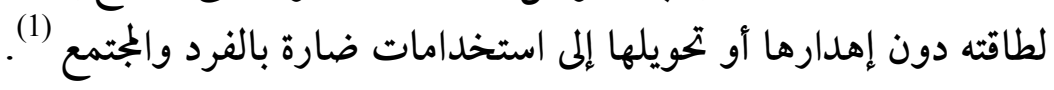
وانطلاقا من هذا أكد وايكمان Eckman وجود العديد من السلوكات

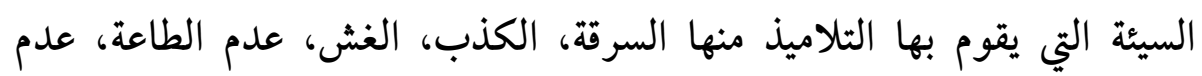

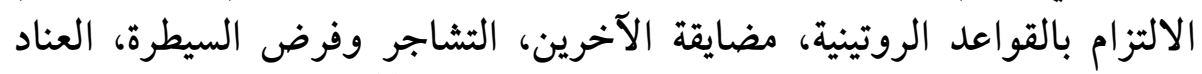

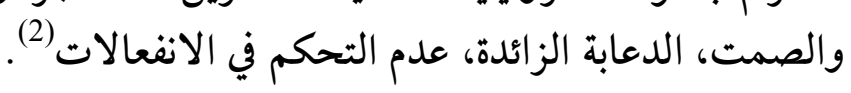
وفي نفس المجال أكد إبراهيم كاظم (1978) وجود سلوكات سيئة يقوم بها

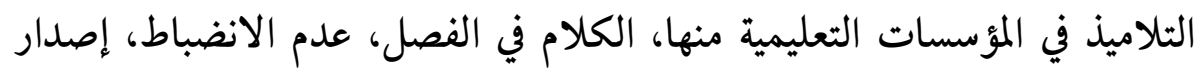

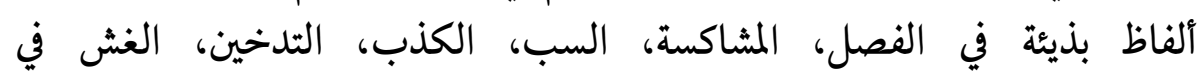
الامتحانات، الاعتداء على المدرسين (3). 


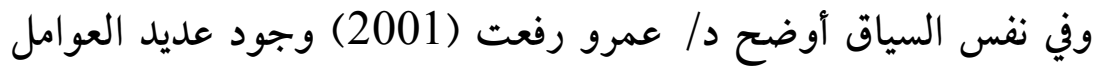

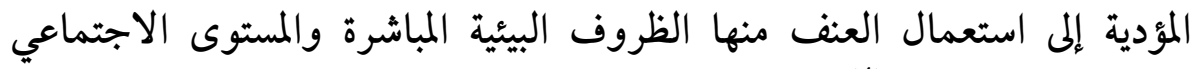
الاقتصادي المنخفض (4). وهذا ما أكدته دراسة سليمة فيلالي (2004-2005) من أن هناك فعلا

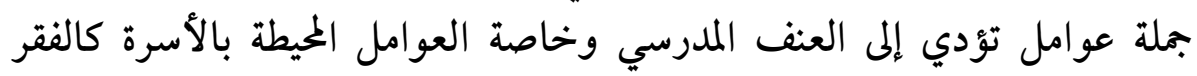

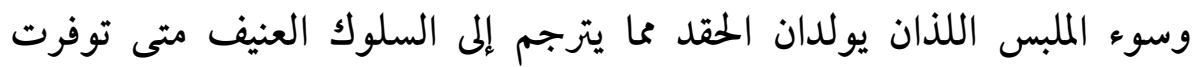

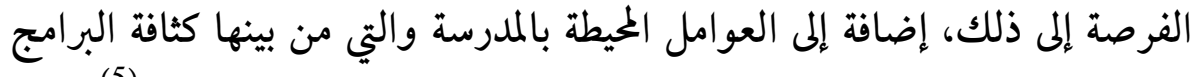

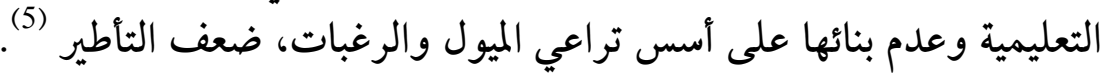

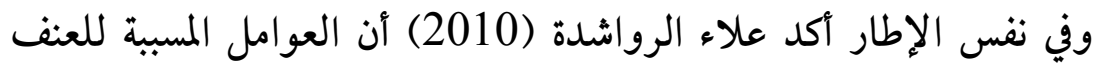

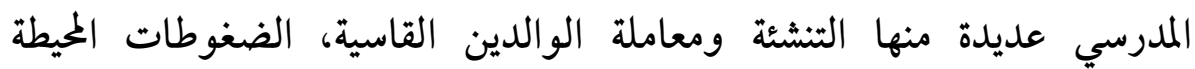

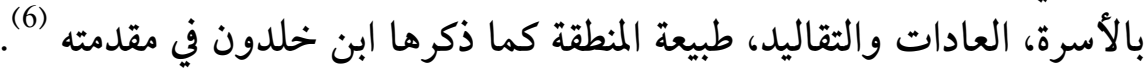

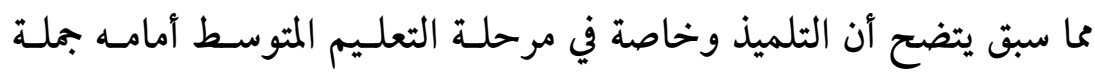

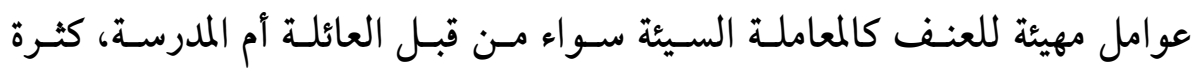

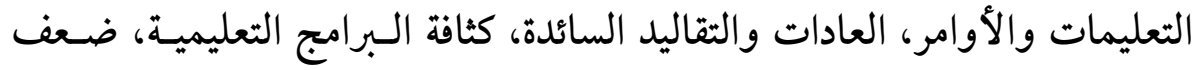

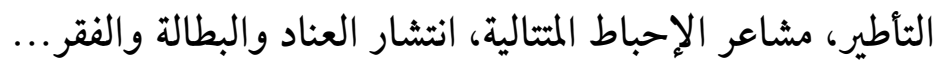

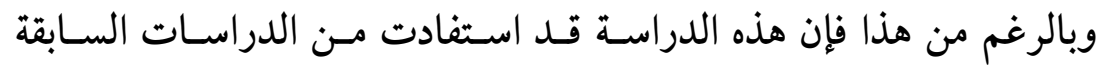

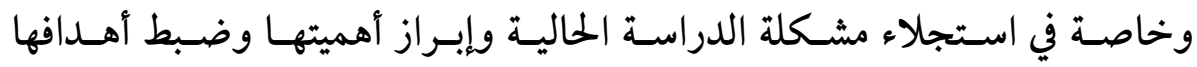

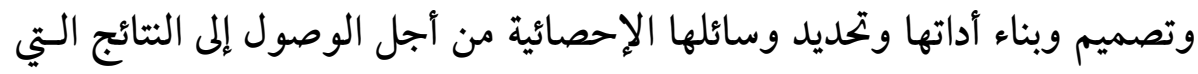

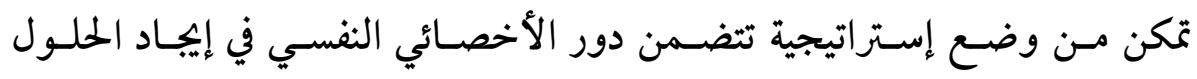
الملائمة للمشكلة أو على الأقل التخفيف منها...

\section{2- 2- مشكلة الدراسة وأسئتها:}

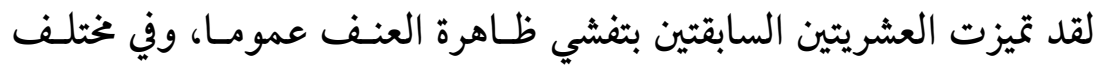

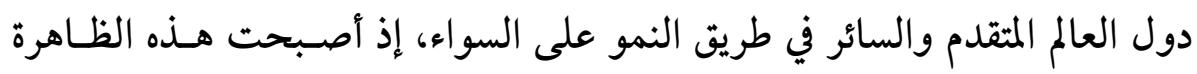




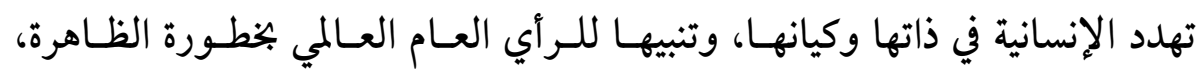

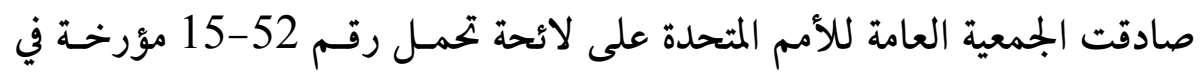

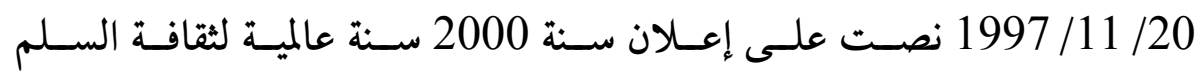

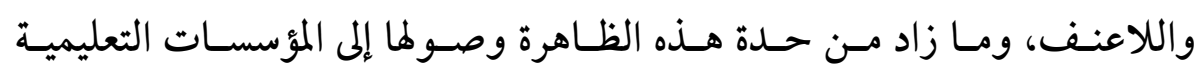

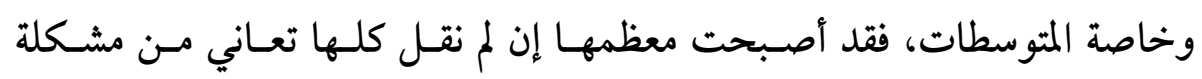

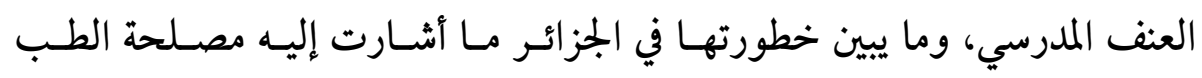

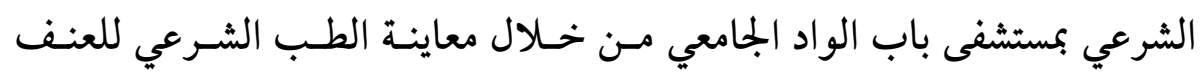

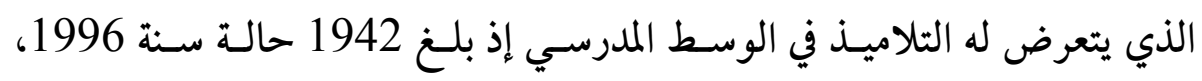

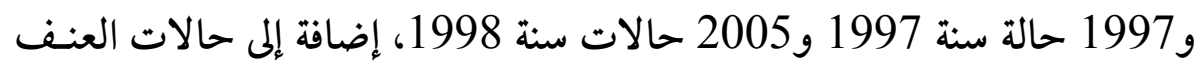

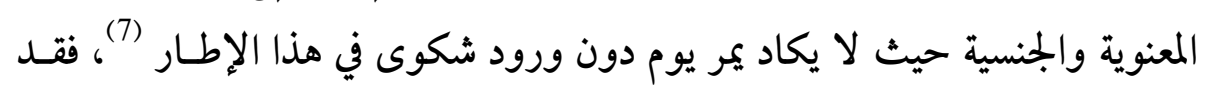

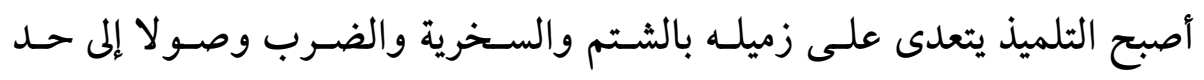

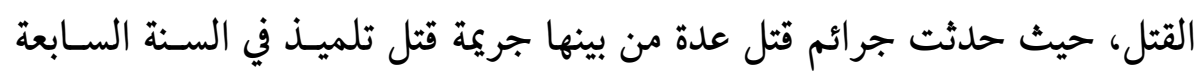

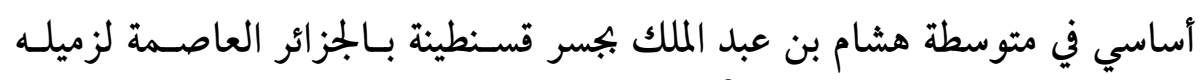

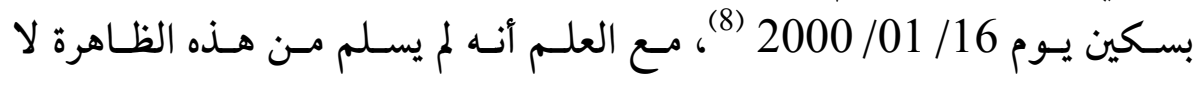

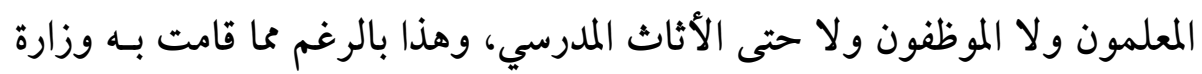

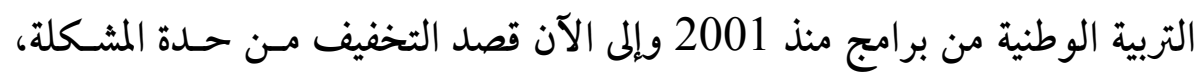

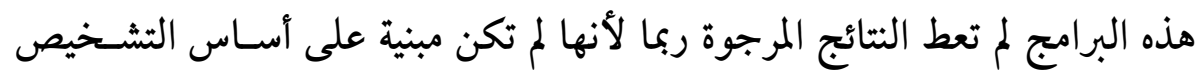
العلمي الذي يبرز بكل موضوعية عواملها وأسبابها. وعليه فإن هذه الدراسة يمكن صياغتها على النحو التالي:

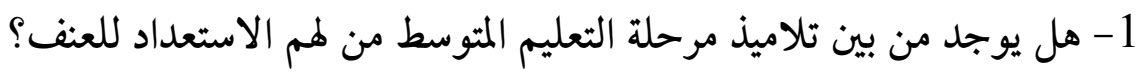

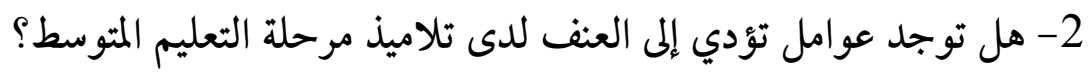

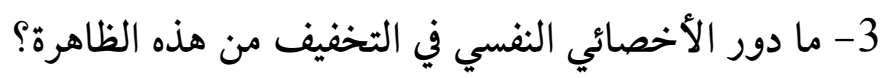


3- 3 - 3رضيات الدراسة:

من خلال الخلفية النظرية للدراسة ومشكلتها يككن صياغة الفرضيات على في

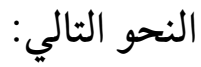
1 - يوجد استعداد للعنف لدى بعض تلاميذ مرحلة التعليم المتوسط. 2- توجد عوامل تؤدي إلى العنف لدى تلاميذ مرحلة التعليم المتوسط.

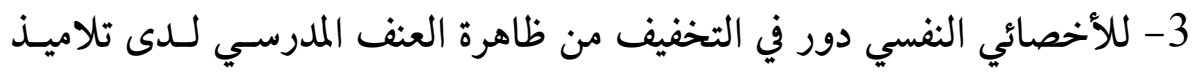
مرحلة التعليم المتوسط.

\section{4- أهمية الدراسة وأمدافها:}

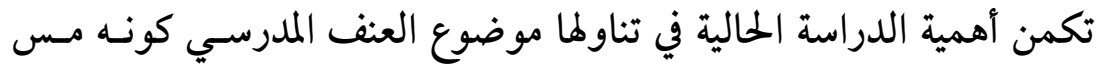

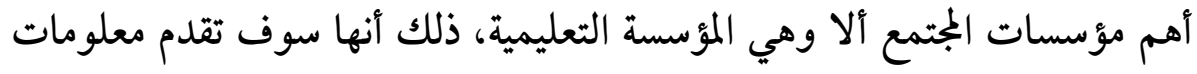

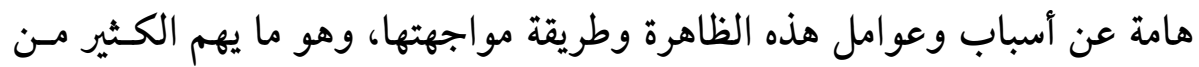

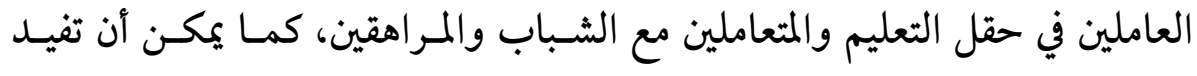

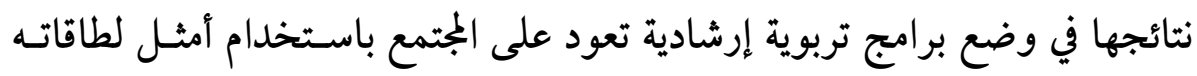

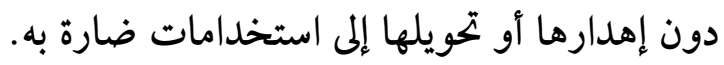

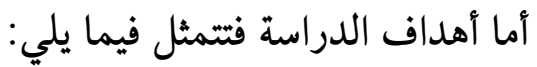

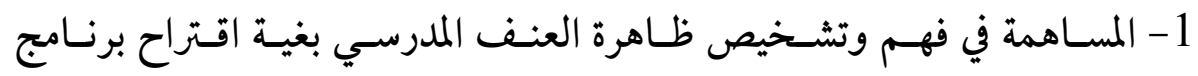
التدخل للتخفيف منها.

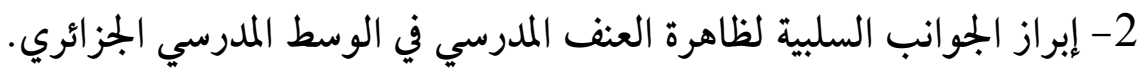

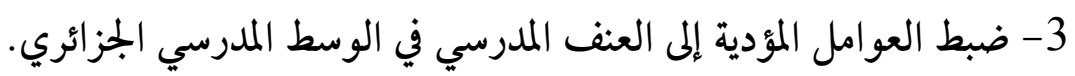

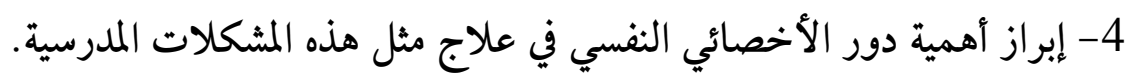

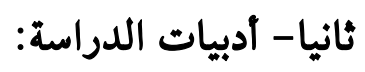

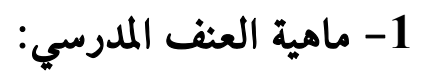

الكل يعلم أن العنف المدرسي مشكلة كبيرة عرفتها المجتمعات في مؤسسـاتها

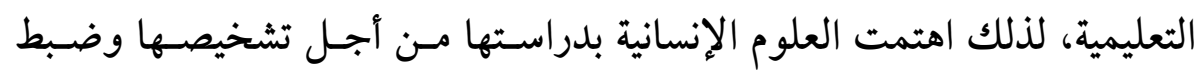


أسبابها الكامنة المتعددة المتداخلة وراءها قصد محاولة إيجاد بدائل علاجية لهـا، فمـا

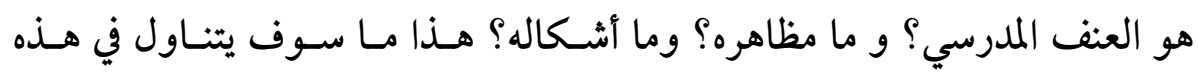

النقطة.

\section{1-1-1 - 1- مفهوم العنف المدرسي:}

عرف العنف تعريفات متعددة، أهمها:

- "لغة التخاطب الأخيرة الممكنة مع الواقع والآخرين، حين يحس المرء

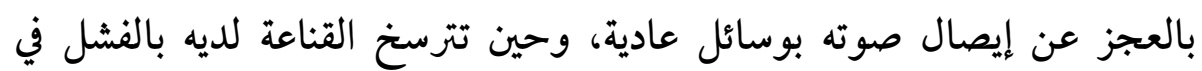

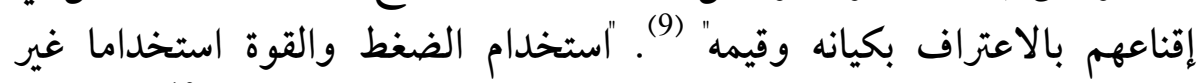

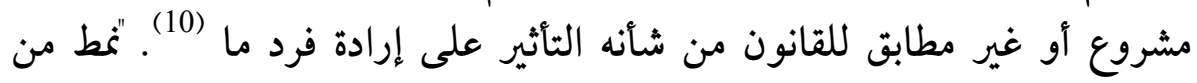

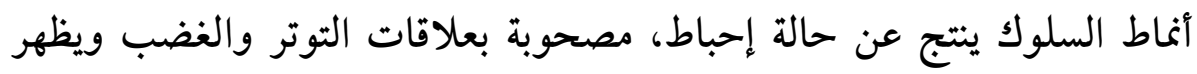

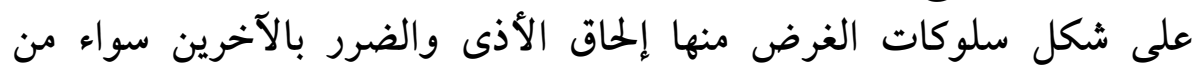

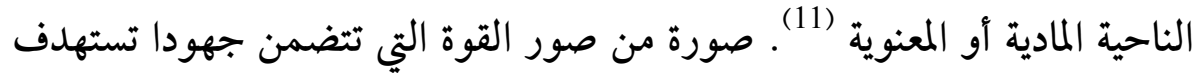

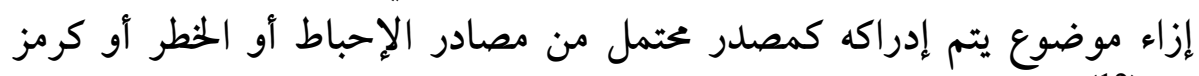

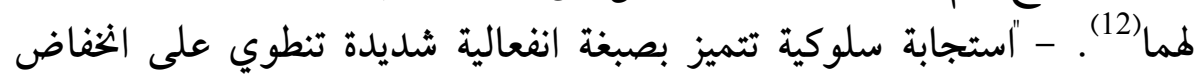
مستوى البصيرة والتفكير، كما يحدث كرد فعل لعنف قائم وهو العنف المضاد (13).

من خـلال التعـاريف السـابقة يمكـن القـول أن العنـف المدرسـي نمـط مـن

السلوك يتسم بالعدوانية يصدر من التلميذ أو مجموعة من التلاميذ ضد تلميذ آخـر

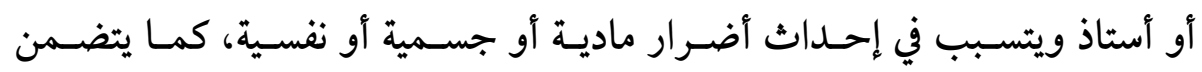

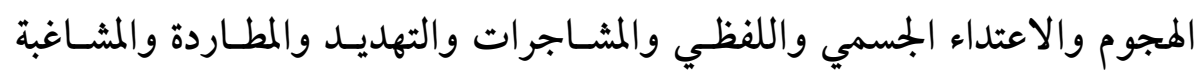
والاعتداء على متلكات التلاميذ والمؤسسة التربوية. 1-2-1 مظاهر العنف المدرسي: 
هناك مظاهر عدة للعنف المدرسي تظهر عندما يقدم التلميذ على التصدي الإقدا

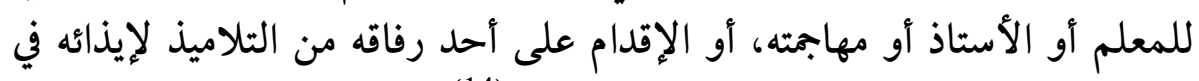

جسمه أو متلكاته، ومن بين تلك المظاهر ما يلي (14): الغضب والانفعال الشديد. - إحـداث الفوضـى العارمـة في حجـــة الدراسـة عـن طريـق الضـحك والكـلام والسخرية...

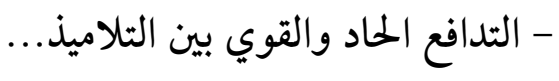

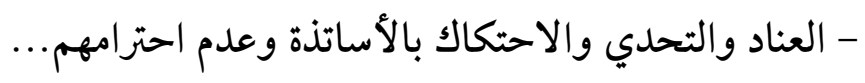

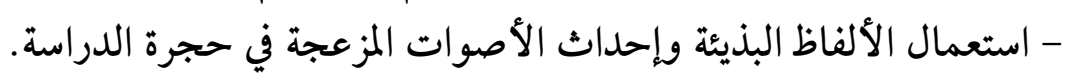

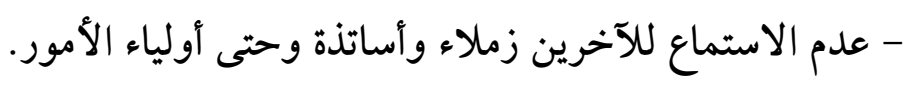

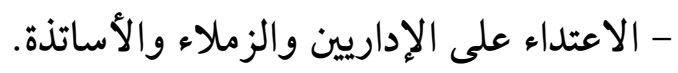

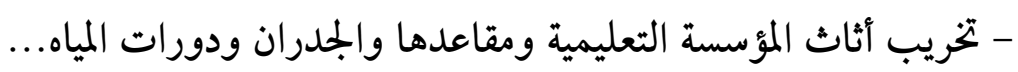

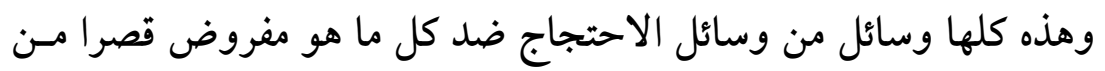

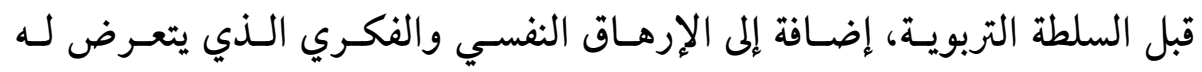

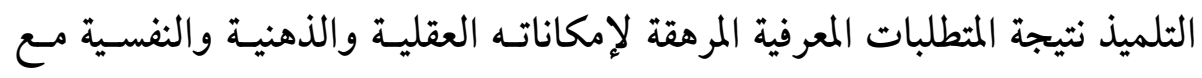

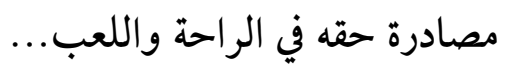

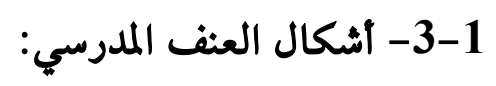

هناك العديد من أشكال العنف المدرسي ينتهجها المنال التلاميذ من بينها:

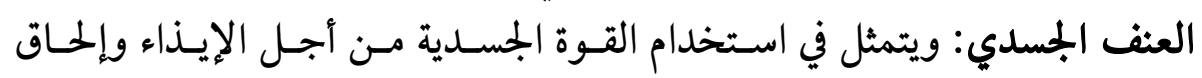

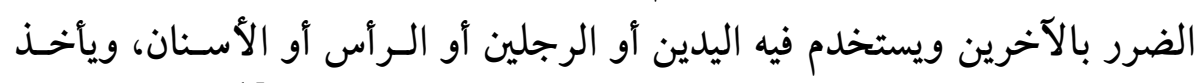

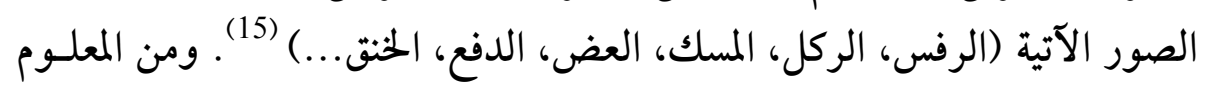

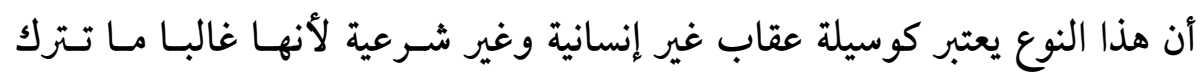

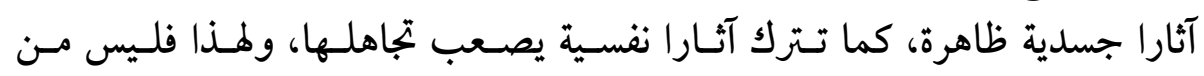

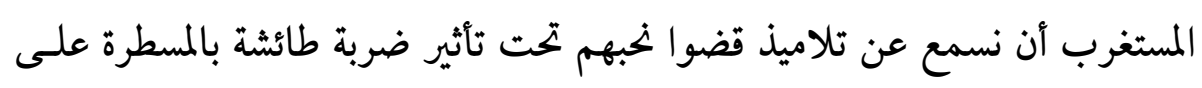


الرأس، أو بتأثير من الخوف الشديد من الضرب أو الركل أو حتى التحقير أو شـــ الأذن...

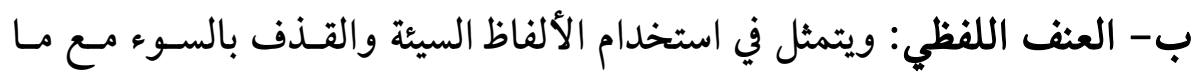

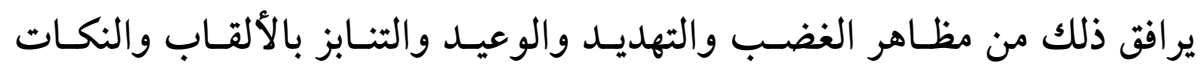
اللاذعة والسخرية.

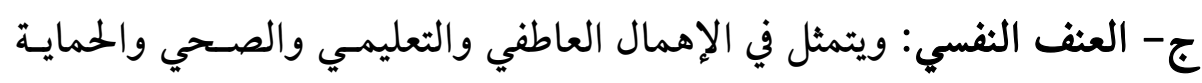

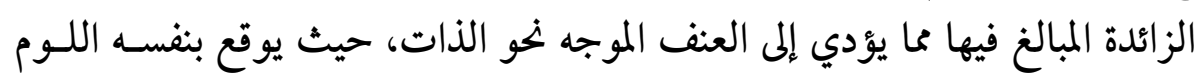

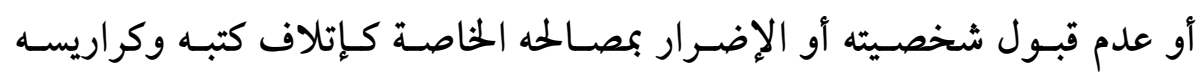

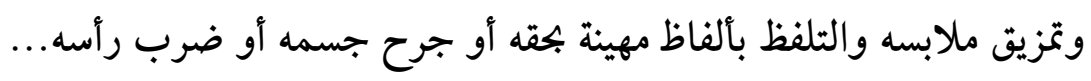

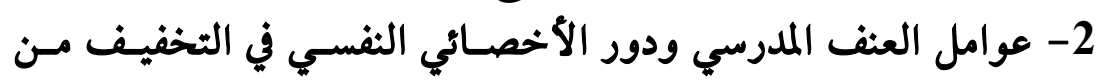
ذلك:

\section{2-1-2 العوامل المودية لظاهرة العنف المدرسي:}

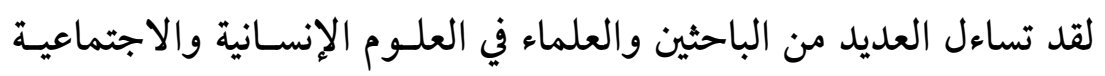

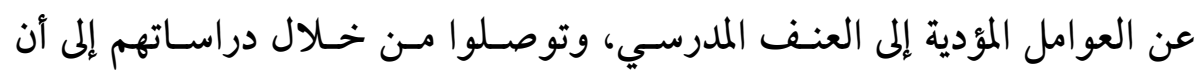

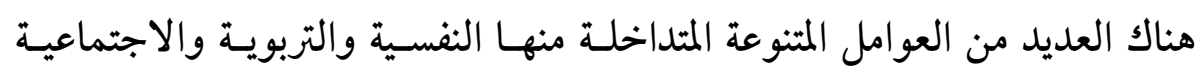

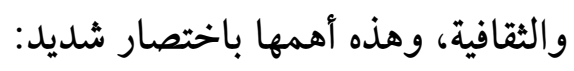

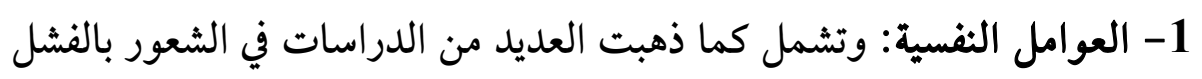

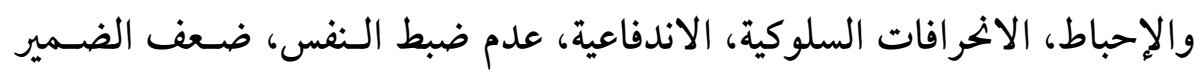

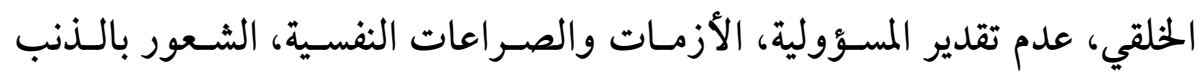

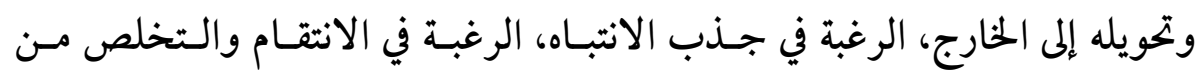

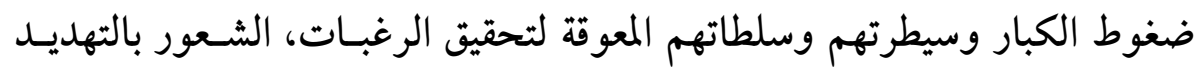

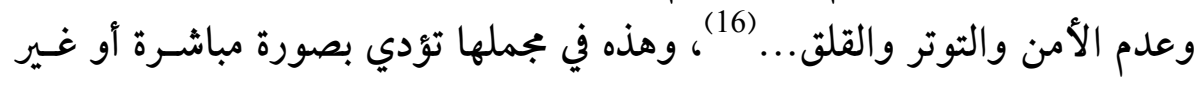
مباشرة إلى ظهور سلوك العنف لدى تلاميذ المرحلة الإعداديـة، إذا أسـاء القـائمون 
على التنشئة الاجتماعية عبر غختلف مؤسســاتها بـــاءا مـن الأسـرة التعامـل معهـم

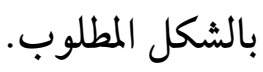

2- العوامل التربوية: وتشمل ارتفاع كثافة الفصول الدراسية، المناهج

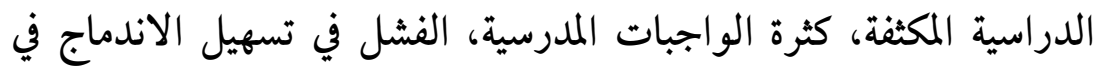

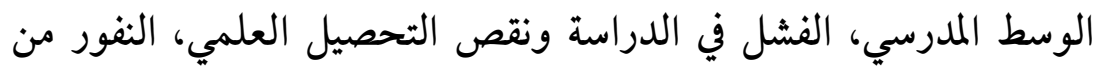

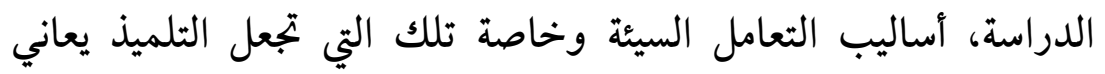

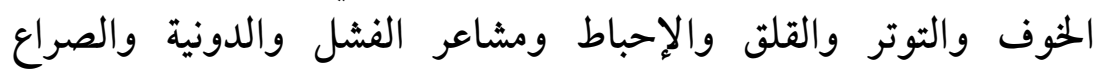

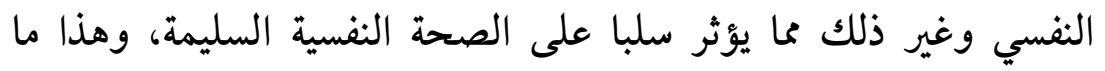

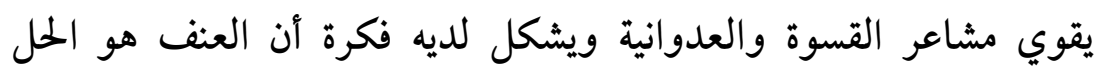
الوحيد لجميع المشاكل والعقبات (17).

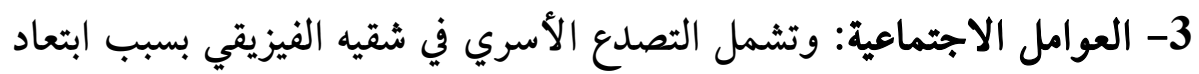

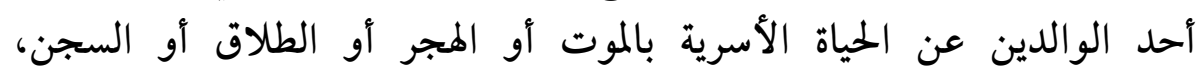

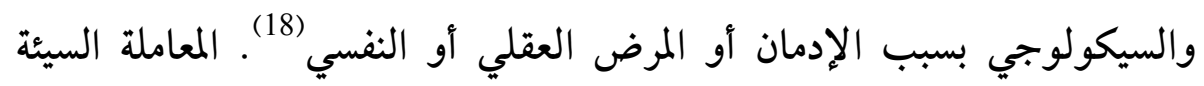

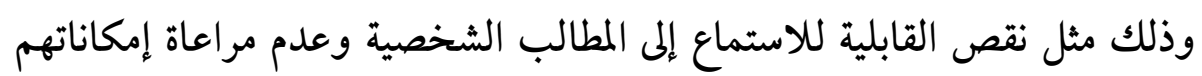

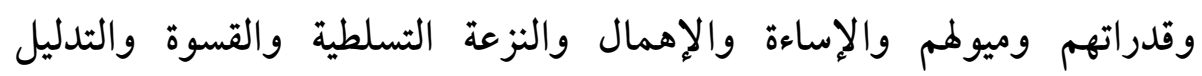

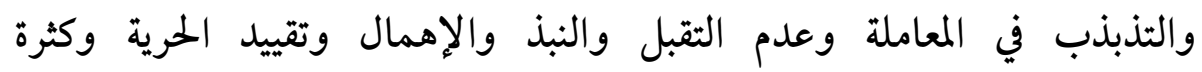

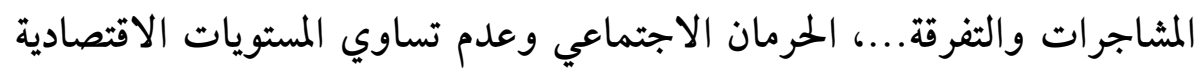

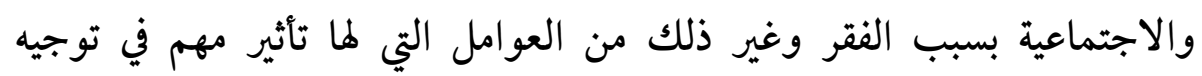

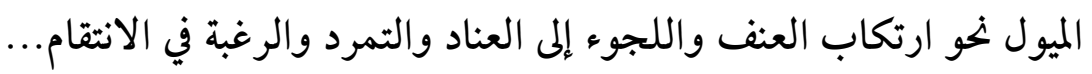

4- العوامل الثقافية: وتشمل كل المشاهد العنيفة التي تعرض في في وسائل المائل

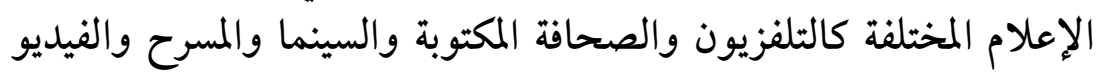

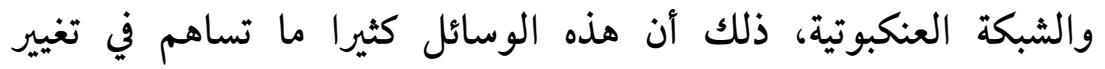

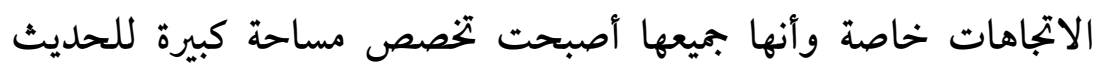

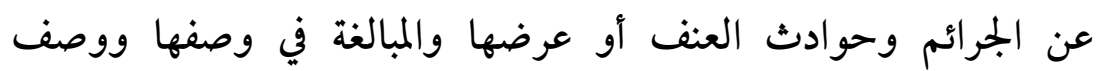


أساليب ارتكابها، فقد أثبتت دراسة أمريكية أجريت على مؤسسات إعادة

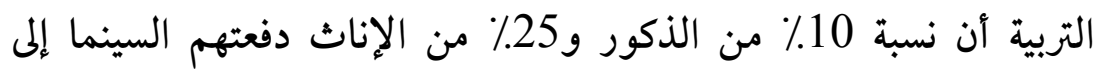

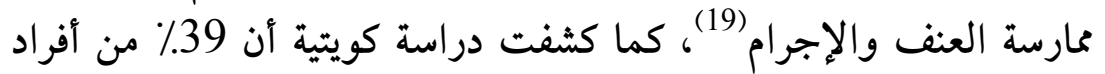
عينة من الشباب يقلدون ما يشاهدونه من أفلام العنف، وتعرف هذه العندة النسبة

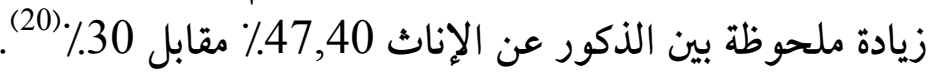

وعلى العموم فإن وسائل الإعلام أصبحت وسيلة لكشف الأساليب والطرق

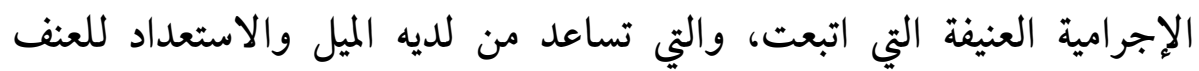
والإجرام في اكتساب خبرات ومعارف تدفعه للقيام بأعمال العنف المختلفة ... 2-2: دور الأخصائي النفسي في التخفيف من ظامرة العنف المدرسي لدى المي

تلاميذ مرحلة التعليم المتوسط:

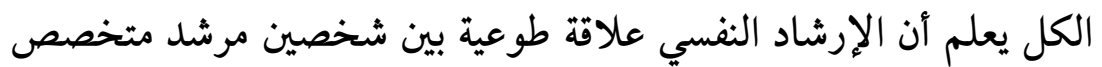

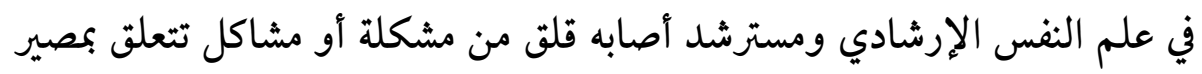

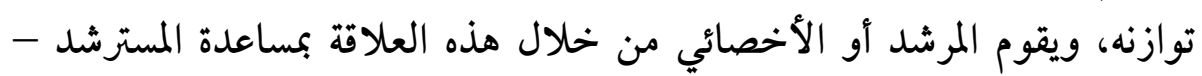

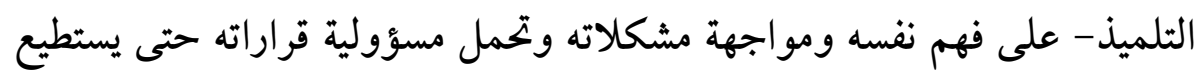

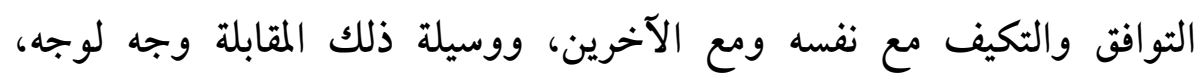

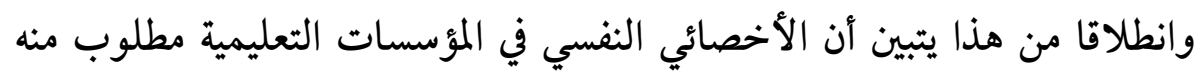

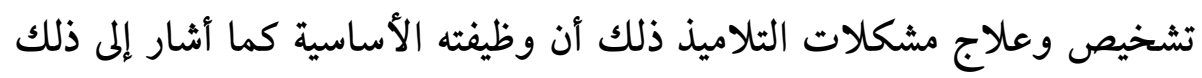

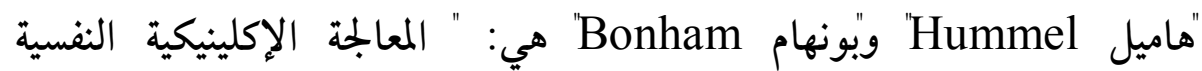
للمحتاجين إليها من الطلاب وأعضاء هيئة التدريس، والقياس بالاختبارات

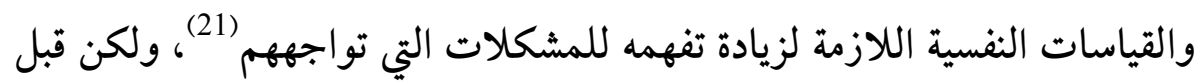

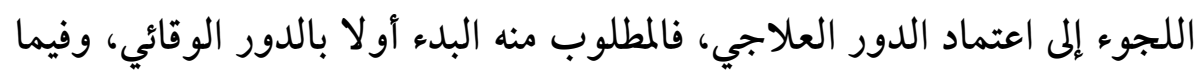
يلي توضيح هاذين الدورين باختصار: أولا- الدور الوقائي: ويقصد به توفير الجو الذي يحقق الصحة النفسية للتلاميذ بـانئ وييول دون تعرضهم لمختلف المشكلات وذلك عن طريق ما يلي: 
1- تربية التلاميذ تربية دينية سليمة معتمدين في ذلك القرآن الكريم "إن مذا

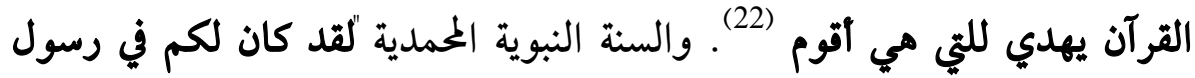
الله أسوة حسنة (23). وهدى الصحم الصحابة رضوان الهان الله عليهم باعتبارهم القدوة في

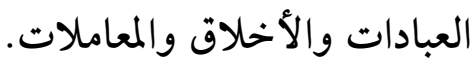

2- تربية التلاميذ على القيم الاجتماعية الراقية كالحب والتعاون والتسامح

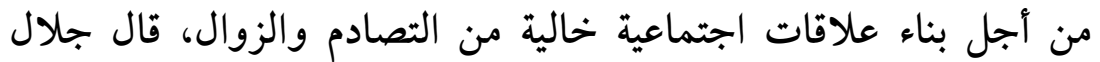

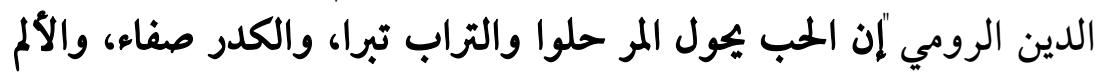

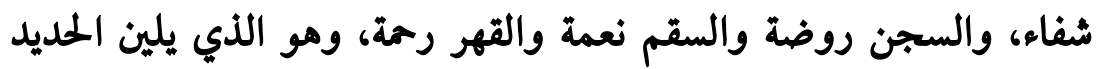

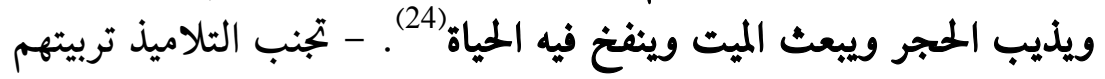

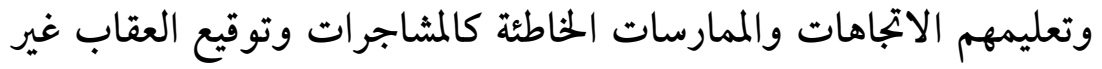

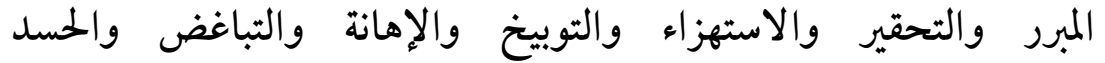

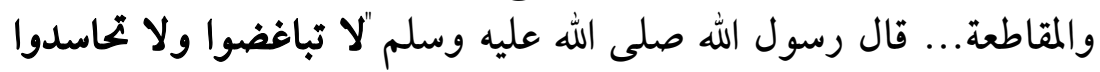

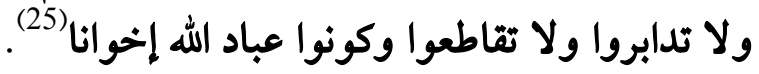

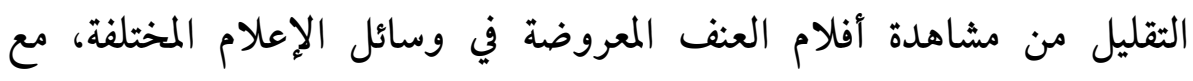
ضرورة توضيح آثارها السلبية على حياة التلاميذ المستقبلية.

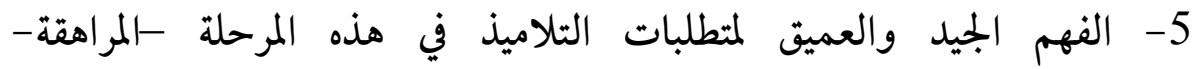
واحتياجاتهم من التربية والتوجيه والاهتمام.

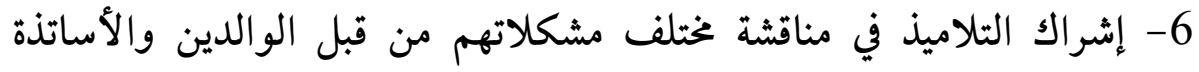
والإداريين من أجل إتاحة الفرصة لكل واحد منهم تكوين وبناء شخصيته والاعتماد على نفسه. 7- مراعاة الفروق الفردية بين التلاميذ في توجيههم وأساليب تدريسهم وتقويم

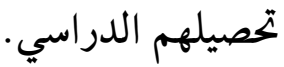


8- تجنب مختلف العقوبات وخاصة البدنية والجماعية والعلنية لأنها تترك جروحا نفسية على أصحابها مما يدفعهم إلى العنف المضاد.

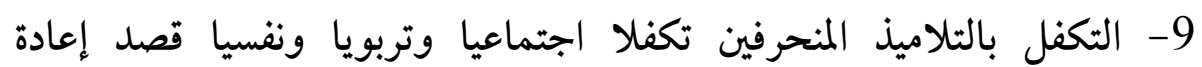
إدماجهم في الحياة المدرسية من جديد. 10- مكافحة ظاهرة العنف في المجتمع عموما باعتبار أن العنف المدرسي هوري هو تكملة للعنف الموجود في الشارع وذلك من خلال ترقية ثقافة السلم واللاعنف... ثانيا- الدور العلاجي: ويقصد به الدراسة التبعية لحالات التلاميذ الذين

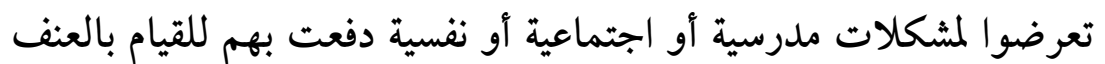

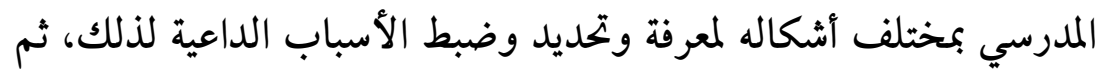

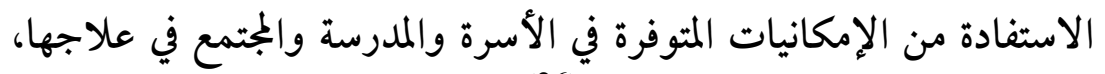

$$
\text { ويتم وفق الخطوات الإجرائية التالية) }
$$

الاستكشاف: تنطلق هذه الخطوة من مبدأ أساسي هو أنه يندر أن يتفق فردان تماما

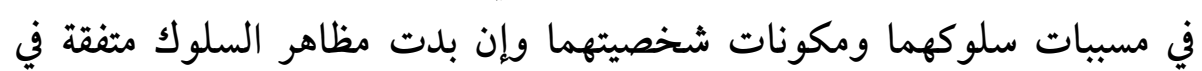

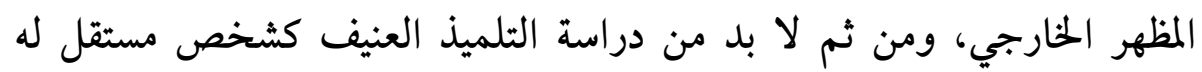
شخصيته وتجاربه في الوسط الذي يعيش فيه، ويتأثر بمؤثرات وقئ وقوى مختلفة أدت اتل

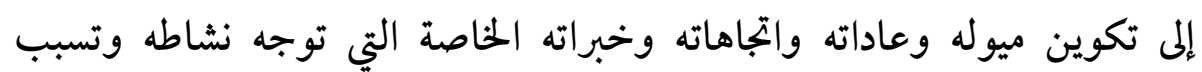

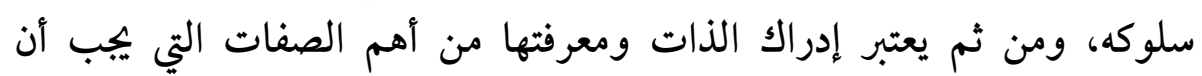

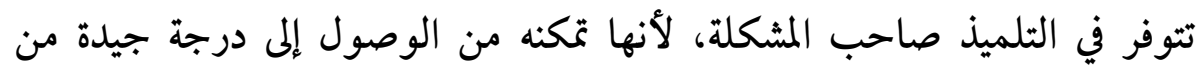

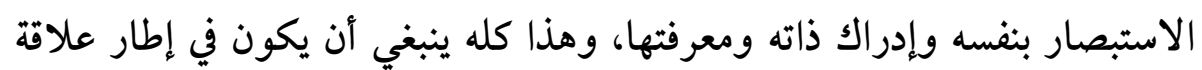

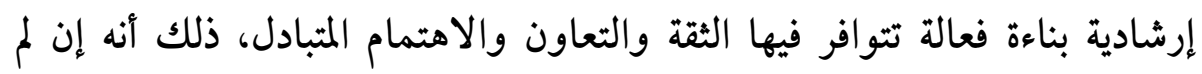

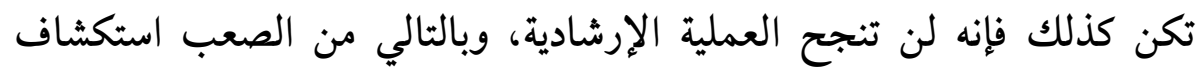

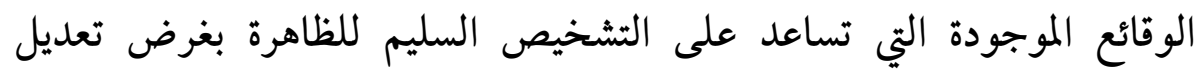
وعلاج السلوك غير المرغوب. 
2- التشخيص: تنطلق هذه الخطوة من هدفين أساسيين تحقيق درجة عالية من فهم

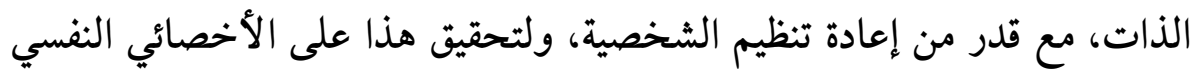

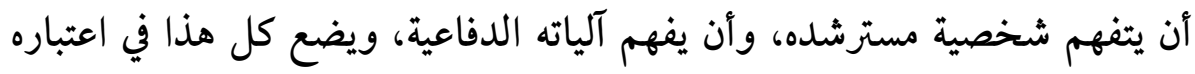

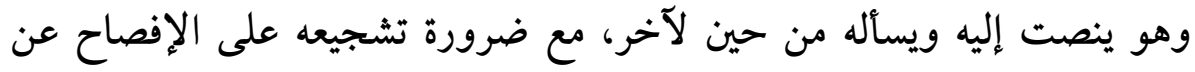

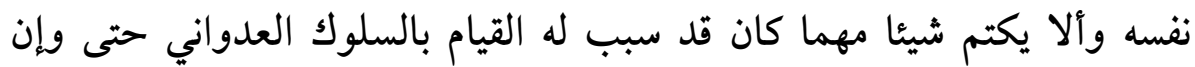

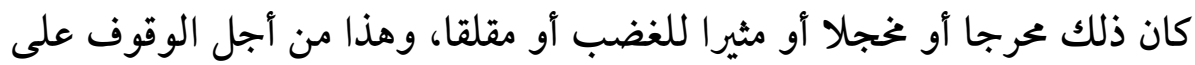

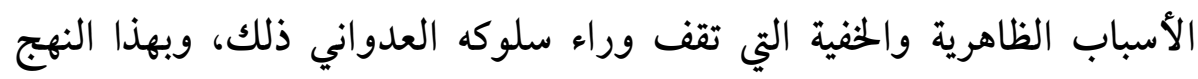

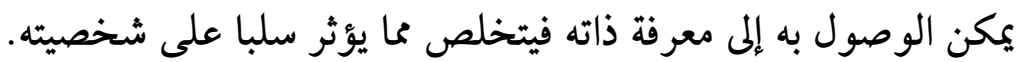

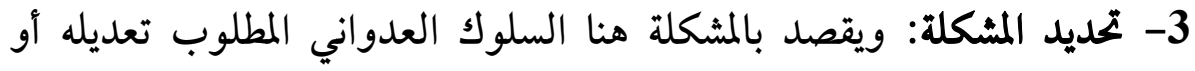

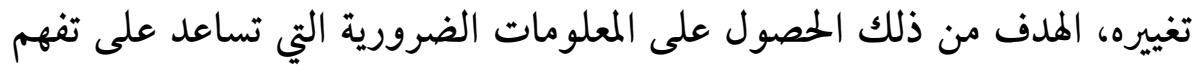
أفضل لذلك السلوك، والمساعدة في صياغة أهداف إرشادية مناسبة واقعية قابلة

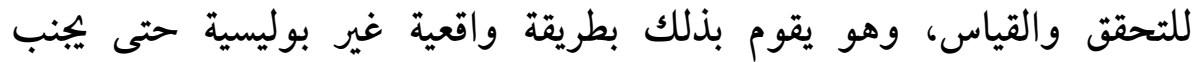

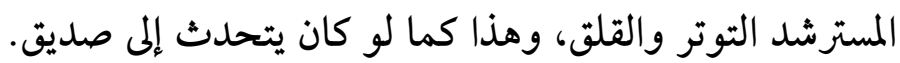

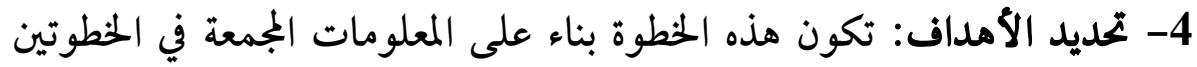

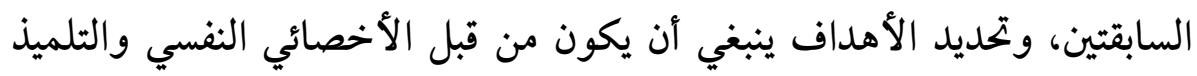

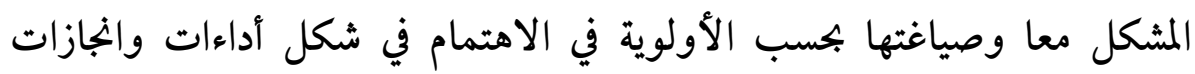

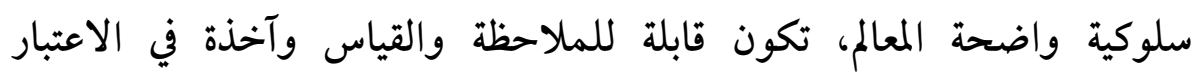

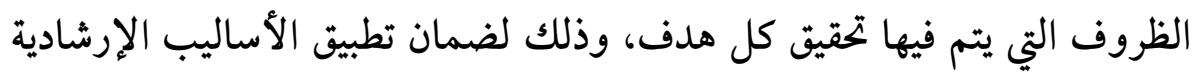

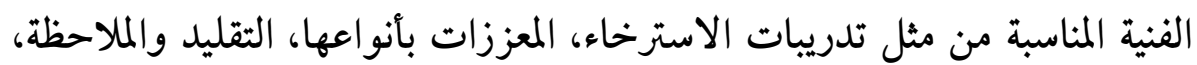

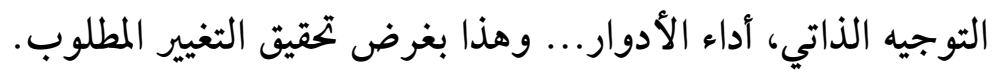

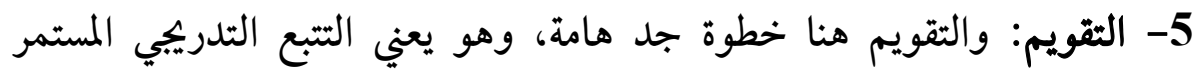

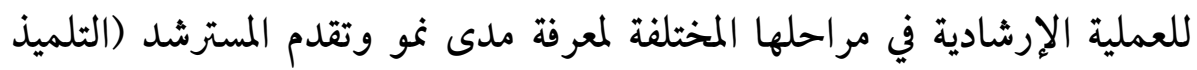

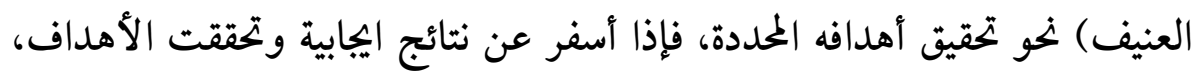


تدعم ويعمل على تحقيقها مستقبلا، أما إذا أسفر عن نتائج سلبية يعاد النظر في

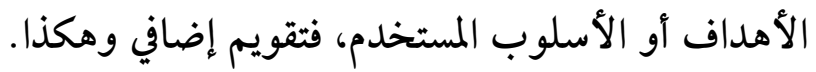

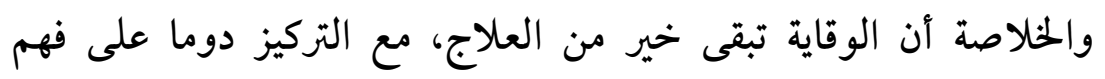

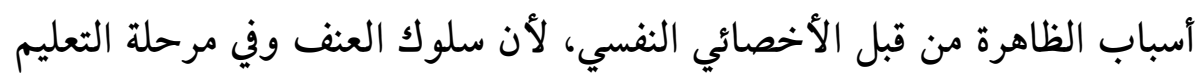

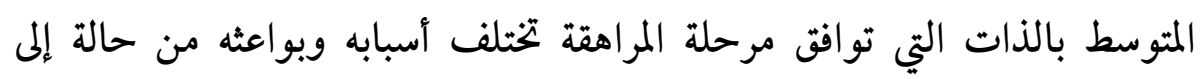

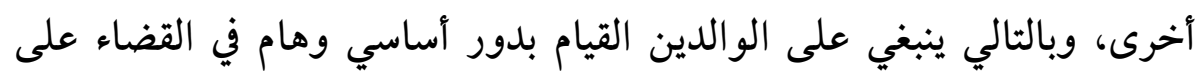

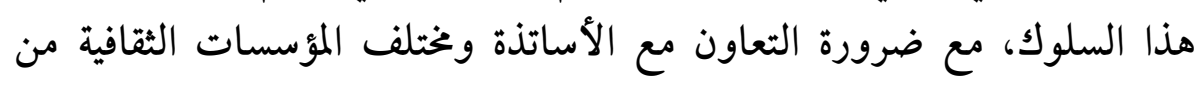
أجل الوصول لمجتمع التلاميذ إلى تكوين فلسفة الحياة.

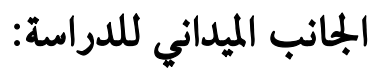
أولا- الأسس المنهجية للدراسة في جانبها الميداني:

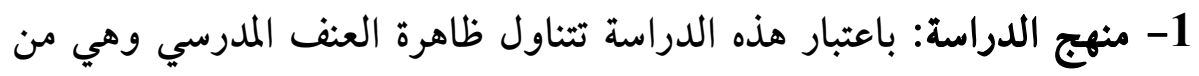

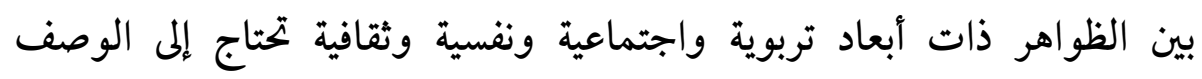

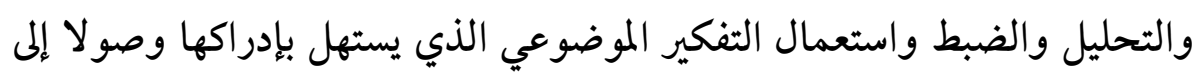

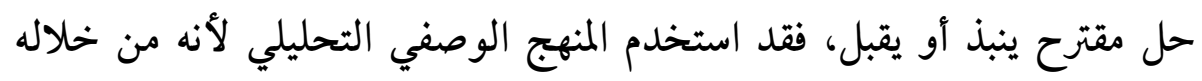

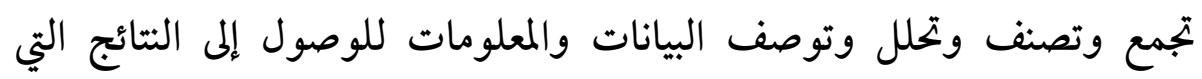

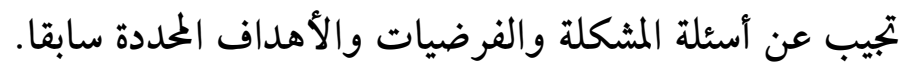

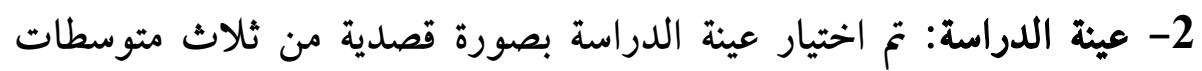

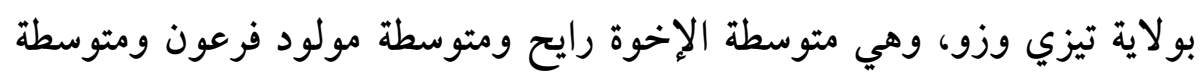

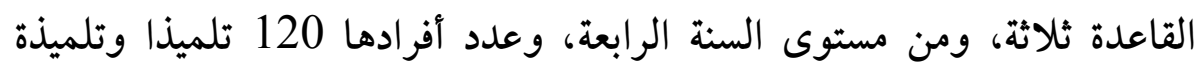

$$
\text { بمعدل } 40 \text { تلميذا من كل متوسطة. }
$$

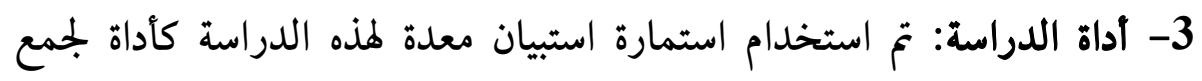

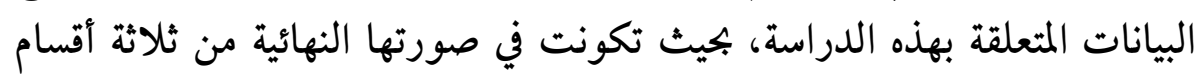

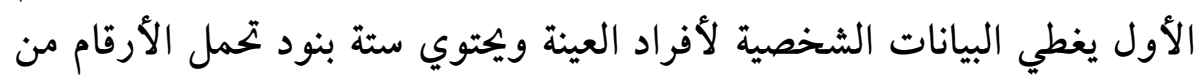

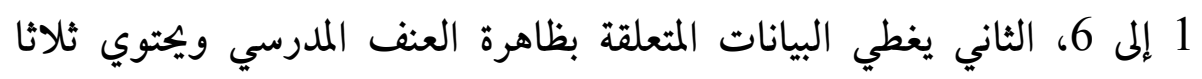


وثلاثين بندا تحمل الأرقام من 07 إلى 39، الثالث يغطي البيانات المتعلقة بدور

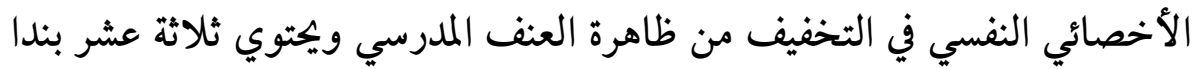

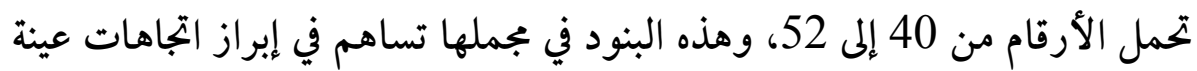
الدراسة نحو ظاهرة العنف المدرسي.

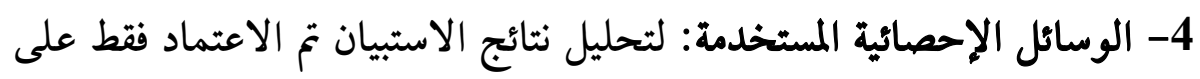

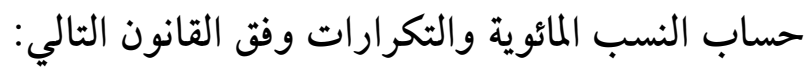

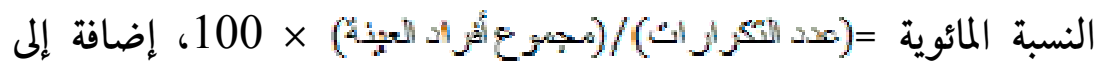

اختبار "ت" t-test بواسطة البرنامج الإحصائي للعلوم الاجتماعية SPSS. ثانيا- نتائج الدراسة ومقترحاتها: 1- عرض النتائج وتحليلها وتفسيرها:

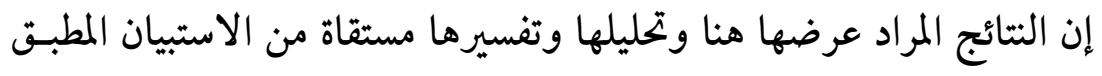
على أفراد العينة، وسوف يكون التركيز فقط على النتـائج ذات الأهميـة لتوضسيح

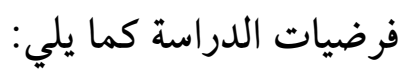
1-1-1: البيانات الشخصية للتلاميذ عينة الدراسة:

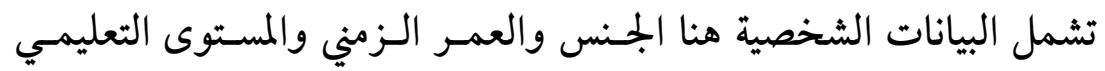

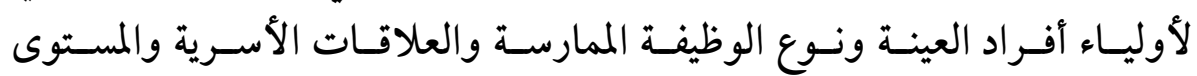

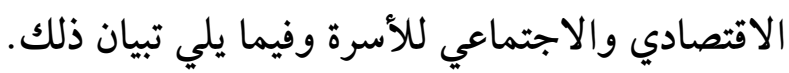

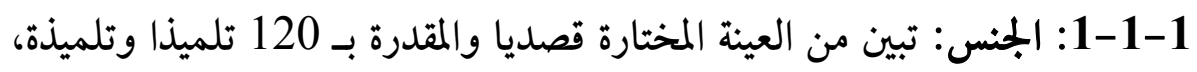

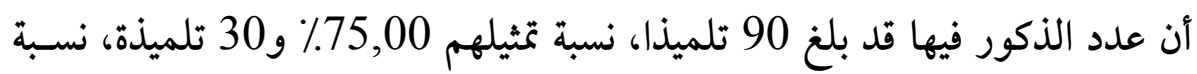

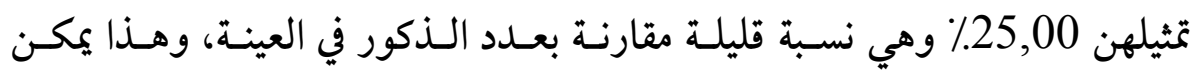
تفسيره بأن الذكور يظهرون السلوكات العنيفة أكثر من الإناث.

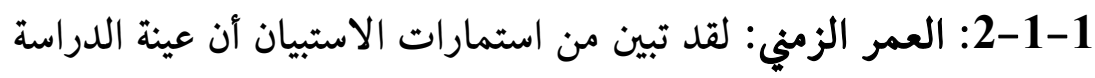

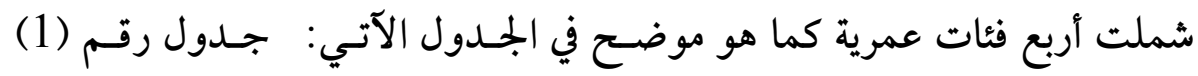
يبين توزيع أفراد العينة حسب العمر الزمني. 


\begin{tabular}{|c|c|c|}
\hline$\%$ & سنوات الميلاد \\
\hline 18,33 & 22 & 1995 \\
\hline 30,00 & 36 & 1996 \\
\hline 35,00 & 42 & 1997 \\
\hline 16,67 & 20 & 1998 \\
\hline 100,00 & 120 & التكرارات \\
\hline
\end{tabular}

المتأمل لمذا الجمدول يتـبين لـه أن 16,67٪ مـن مجمـوع أفـراد العينـة دخلـوا

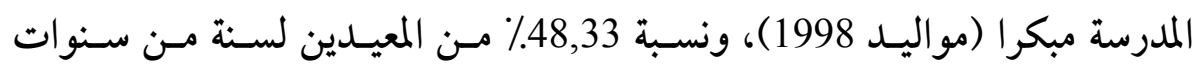

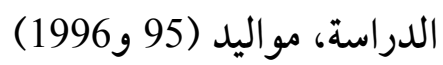
ذ1 ف-2-3: المستوى التعليمي للوالدين ونوع الوظيفة الممارسة من قبلهما: يمكن توضسيح

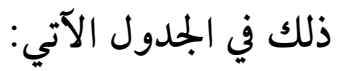
جدول رقم (2) يبين المستوى التعليمي لأولياء أفراد العينة ونوع الوظيفة الممارسة.

\begin{tabular}{|c|c|c|c|c|c|c|c|c|c|}
\hline \multicolumn{2}{|c|}{ الوالدة } & \multicolumn{2}{|c|}{ الوالد } & \multirow[t]{2}{*}{ نوع الوظيفة } & \multicolumn{2}{|r|}{ الو الدة } & \multicolumn{2}{|r|}{ الو الد } & \multirow{2}{*}{ التعليميتوى } \\
\hline$\%$ & $ت$ & $\%$ & $ت$ & & $\%$ & ت & $\%$ & ت & \\
\hline 25,00 & 30 & 23,33 & 28 & بدون عمل & 16,67 & 20 & 08,34 & 10 & أمي \\
\hline 13,33 & 16 & 15,00 & 18 & متقاعدون & 18,33 & 22 & 25,00 & 30 & ابتدائي \\
\hline 33,33 & 40 & 28,33 & 34 & عسيط لمـل & 20,00 & 24 & 25,83 & 31 & متوسط \\
\hline 26,67 & 32 & 25,00 & 31 & إطارات & 28,33 & 34 & 28,33 & 34 & ثانوي \\
\hline 01,67 & 02 & 08,34 & 10 & مهن حرة & 16,67 & 20 & 12,50 & 15 & جامعي \\
\hline 100 & 120 & 100 & 120 & المجموع & 100 & 120 & 100 & 120 & الججموع \\
\hline
\end{tabular}

المتأمل لمذا الجلدول (2) يتـبين لـه أن أغلبيـة أوليـاء أفراد العينـة مـن ذوي المستوى التعليمي الأدنى وبدون عمل أو متقاعدون وخاصة الأمهات.

4-2-1 : العلاقات الأسرية والمستوى الاقتصادي للأسرة: يمكن توضيح ذلك في الجدول الآتي:

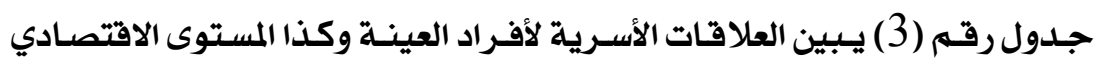

للأسرة.

\begin{tabular}{|c|c|c|c|c|c|}
\hline$\%$ & ت & المستوى الاقتصادي للأسرة & $\%$ & ت & نوعية العلاقات \\
\hline
\end{tabular}


العدد 07 ؛ سبتمبر 2013

\begin{tabular}{|c|c|c|c|c|c|}
\hline 08,33 & 10 & مرتفع & 25,00 & 30 & جيدة \\
\hline 41,67 & 50 & متوسط & 58,33 & 70 & عادية \\
\hline 33,33 & 40 & منخفض & 10,00 & 12 & سيئة \\
\hline 16,67 & 20 & منخفض جدا & 06,67 & 08 & سيئة جدا \\
\hline 100 & 120 & المجموع & 100 & 120 & المجموع \\
\hline
\end{tabular}

يتبين من هذا الجمدول(3)أن جل أفراد العينة أكدوا بـأن العلاقـات الأسـرية

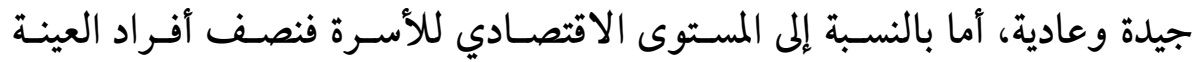

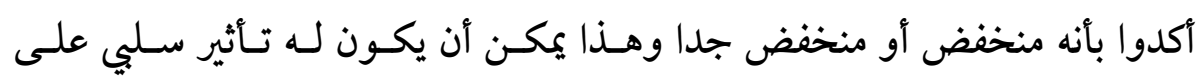
التلاميذ.

2.1: البيانات المتعلقة بوجهات نظر أفراد العينة في كل ما له علاقة بسلوكاتهم

العدوانية:

1.2.1: البيانات المتعلقة بالاسـتعداد للعنـف: تشــمل سـتة بنسود، وهـي تتعلـق بالفرضية الأولى القائلة بـ" يوجد استعداد للعنف لدى بعض تلانلاميذ مرحلة التعليم

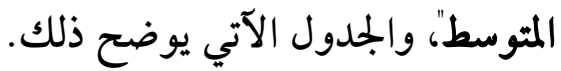
جــدول رقـم (4) يـبين مـا إذا كـان أفـراد عينـة التلاميـذ لـديهم اسـتعداد للقيـام بالسلوكات العدوانية

\begin{tabular}{|c|c|c|c|c|c|}
\hline \multicolumn{2}{|c|}{$\gamma$} & \multicolumn{2}{|c|}{ نعم } & \multirow[t]{2}{*}{ مضمون البنود } & \multirow[t]{2}{*}{ 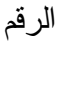 } \\
\hline$\%$ & ت & $\%$ & ت & & \\
\hline 41,67 & 50 & 58,33 & 70 & كثيرا ما أسبب الأذى للآخرين. & 7 \\
\hline 36,67 & 44 & 63,33 & 76 & كثيرا ما أقذف الآخرين بالأشياء الموجودة أمامي. & 8 \\
\hline 40,00 & 48 & 60,00 & 72 & كثيرا ما أتشاجر مع زملائي في المتوسطة لأتفه الأسباب. & 9 \\
\hline 33,33 & 40 & 66,67 & 80 & لا أتردد في استعمال العنف الجسلدي أو اللفظي مـع الآخرين. & 10 \\
\hline 33,33 & 40 & 66,67 & 80 & أعتبر العنف الطريق الأمثل لاسترجاع حقي. & 11 \\
\hline
\end{tabular}




\begin{tabular}{|l|l|l|l|l|l|}
\hline 41,67 & 50 & 58,33 & 70 & & \\
\hline
\end{tabular}

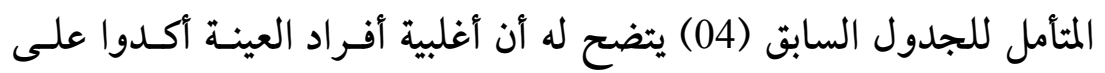

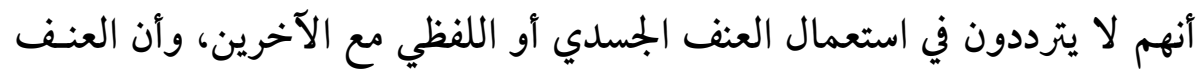

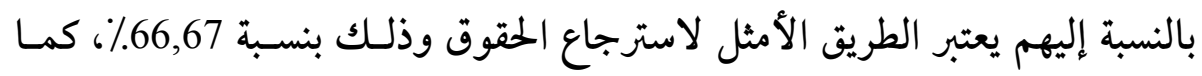

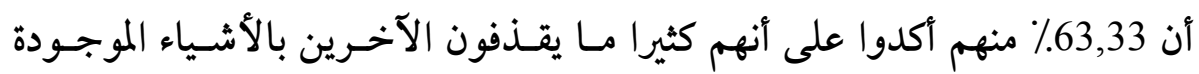

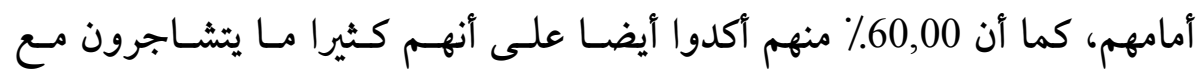

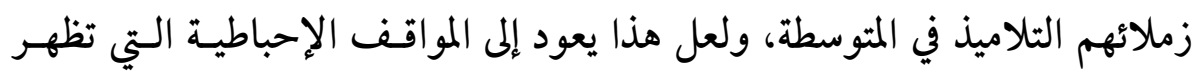

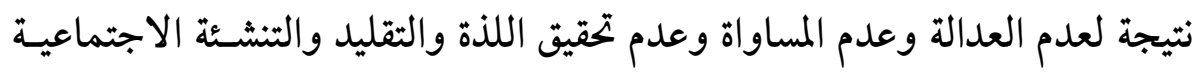

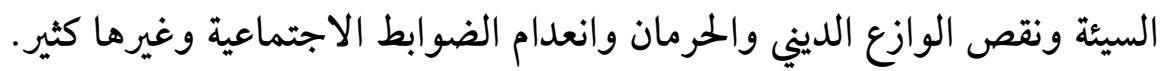

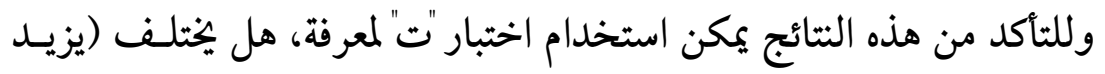

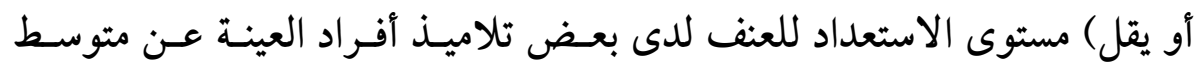

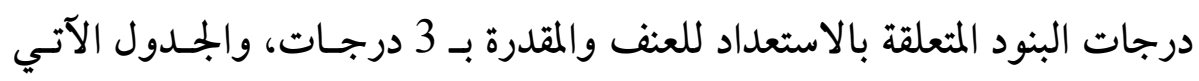
يوضح ذلك.

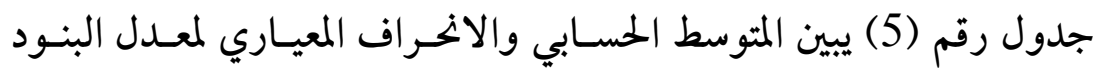

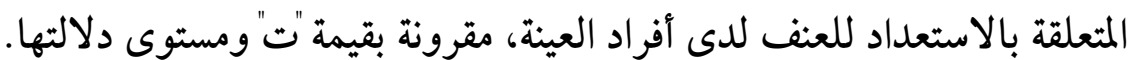

\begin{tabular}{|c|c|c|c|c|c|c|c|c|}
\hline مستوى الدلالة & لدرجة & قيمة ت & للمتوسط الخطأ & المعياري & المعد & العسابي & أفر اد & للاستف اللفداد \\
\hline ,000 & 119 & 6,983 & 0,11 & 1,15 & 0,73 & 3,73 & 120 & \\
\hline
\end{tabular}




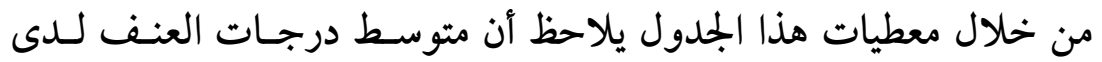

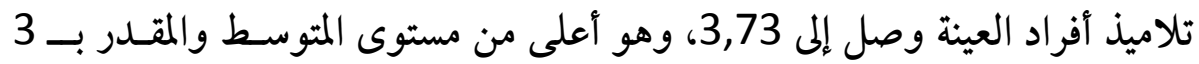

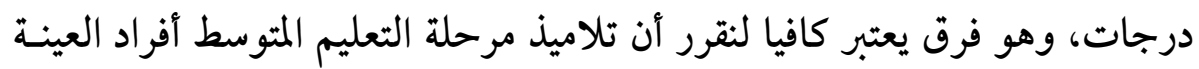

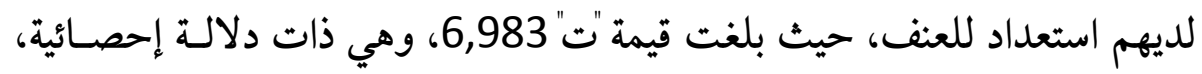

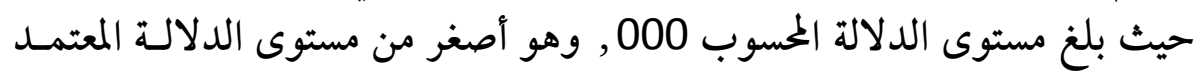

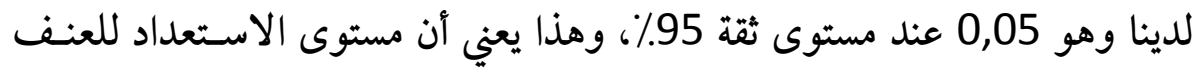

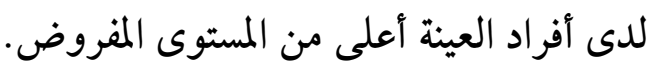
وانطلاقا من المعطيات الواردة في الجدولين السـابقين (4 و5)، يمكـن القـول

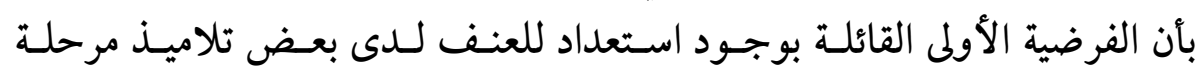
التعليم المتوسط قد تحققت.

2.2.1: البيانات المتعلقة بالعوامل أو الأسباب المؤدية للعنف المدرمسي: تشـمل

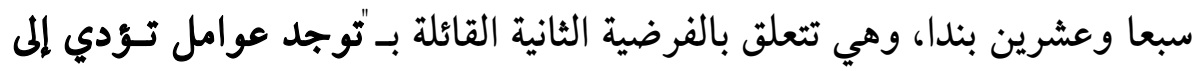

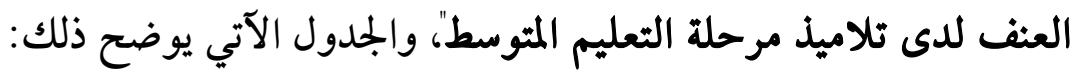

جدول رقم (6) يبين مختلف العوامل المؤدية للعنـف المدرسـي بحسـب وجهـة نظـر

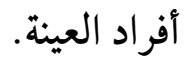

\begin{tabular}{|c|c|c|c|c|c|c|}
\hline \multicolumn{2}{|l|}{ ע } & \multicolumn{2}{|c|}{ 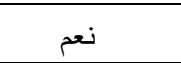 } & \multirow{2}{*}{ العوعية - امل } & \multirow[t]{2}{*}{ 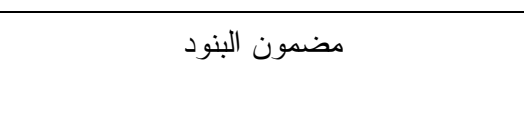 } & \multirow{2}{*}{$\bar{x}$} \\
\hline$\%$ & $ت$ & $\%$ & $ت$ & & & \\
\hline 42,50 & 51 & 57,50 & 69 & \multirow{4}{*}{$\begin{array}{l}\overline{3} \\
\overline{3} \\
\text { 高 } \\
\frac{3}{3}\end{array}$} & أحطم كل ما أجده أمامي إذا كنت غاضبا. & 13 \\
\hline 58,33 & 70 & 41,67 & 50 & & أصر خ لأتفه الأسباب و أبكي أحيانا. & 14 \\
\hline 35,00 & 42 & 65,00 & 78 & & أتعامل بخشونة مع الآخرين. & 15 \\
\hline 25,00 & 30 & 75,00 & 90 & & والقعرض كثير اللصر اعات النفسية كــالخوف & 16 \\
\hline
\end{tabular}




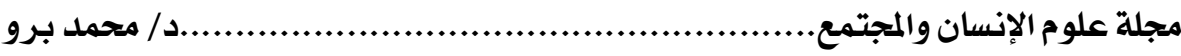

\begin{tabular}{|c|c|c|c|c|c|c|}
\hline 33,33 & 40 & 66,67 & 80 & & أثنعر بالفشل و الإحباط دوما. & 17 \\
\hline 33,33 & 40 & 66,67 & 80 & & كثثر ا ما أثنعر بعدم الأمن و التوتر. & 18 \\
\hline 66,67 & 80 & 33,33 & 40 & & أثنعر بالذنب عندما أتعدى على الآخرين. & 19 \\
\hline 23,33 & 28 & 76,67 & 92 & & و لا أسنطيع تقدير المســؤولية تجــاه نفســي & 20 \\
\hline 38,33 & 46 & 61,67 & 74 & \multirow{7}{*}{$\begin{array}{l}\frac{3}{3} \\
\frac{3}{3} \\
\frac{3}{3} \\
3\end{array}$} & أجد صــعوبة فــي الانـــماج فــي الوســــ & 21 \\
\hline 37,50 & 45 & 62,50 & 75 & & أنفر من الدراسة بســبب تقضــيل الأســاتذة & 22 \\
\hline 37,50 & 45 & 62,50 & 75 & & و أكره الأساتذة بســبب العقوبــات الجماعبــة & 23 \\
\hline 45,00 & 54 & 55,00 & 66 & & و أنشعر بالضيق و القلق بسبب اكتظاظ الأقســـام & 24 \\
\hline 30,00 & 36 & 70,00 & 84 & & و المساعدون التربويون و الأســاتذة منشــددون & 25 \\
\hline 50,00 & 60 & 50,00 & 60 & & 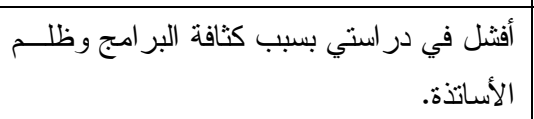 & 26 \\
\hline 58,33 & 70 & 41,67 & 50 & & لدي نقص في الدافعية للتحصيل الدر اسي. & 27 \\
\hline 66,67 & 80 & 33,33 & 40 & \multirow{6}{*}{$\begin{array}{l}\overline{3} \\
\overline{3} \\
\overline{3} \\
.7 \\
\frac{3}{y}\end{array}$} & و عقاب و الداتنتي لي بيـــبـ حقــدي لزملائسـي & 28 \\
\hline 60,00 & 72 & 40,00 & 48 & & للآخرين. & 29 \\
\hline 68,33 & 82 & 31,67 & 38 & & أكره الجميع بسبب الفقر الذي أعيثـــه فــي & 30 \\
\hline 70,00 & 84 & 30,00 & 36 & & كثرة المشكلات الأسرية يــدفعني لاســتعمال & 31 \\
\hline 36,67 & 44 & 63,33 & 76 & & قلتة الاهتمام بمطالبي الثخصية، يؤدي بي إلى & 32 \\
\hline 20,00 & 24 & 80,00 & 96 & & 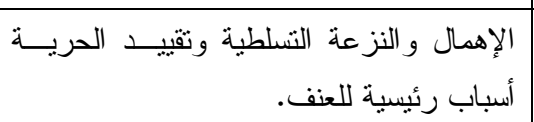 & 33 \\
\hline 51,67 & 62 & 48,33 & 58 & -7 & وسائل الإعلام المختلفة تشيد بالقوي فقط. & 34 \\
\hline
\end{tabular}


العدد 07 ؛ سبتمبر 2013

\begin{tabular}{|c|c|c|c|c|c|}
\hline 18,33 & 22 & 81,67 & 98 & أحب مشاهدة الأفلام البولبسية العنيفة. & 35 \\
\hline 16,67 & 20 & 83,33 & 100 & مختلف الجب المقالات الصحفية التي تتحــدث عــن & 36 \\
\hline 16,67 & 20 & 83,33 & 100 & الإعلام تدفع للعنف. العنيفة التي تعرض عبـر وســائل & 37 \\
\hline 41,67 & 50 & 58,33 & 70 & العنف وسيلة جيدة في التعامل مع الآخرين. & 38 \\
\hline 33,33 & 40 & 66,67 & 80 & أفلام العنف و الجريمة تعلمني أساليب وتقنيات & 39 \\
\hline
\end{tabular}

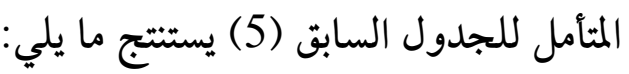

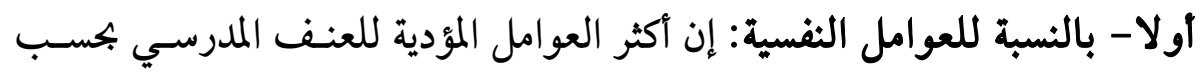

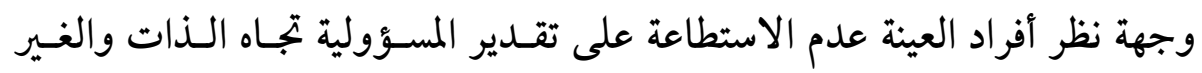

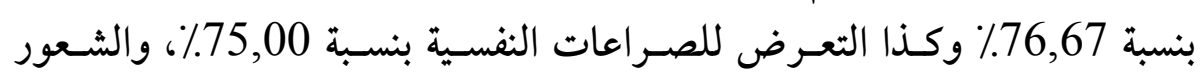

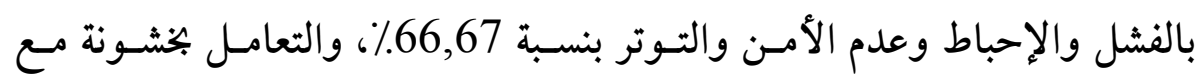

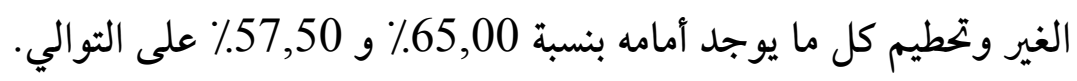

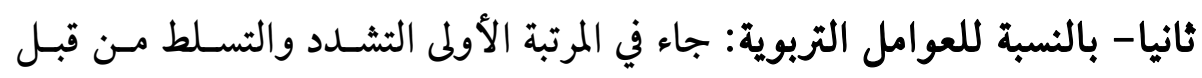

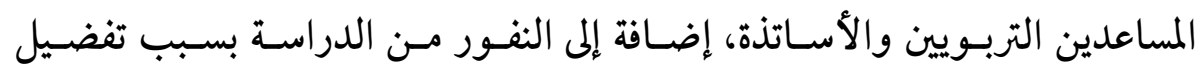

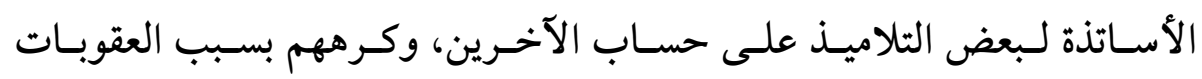

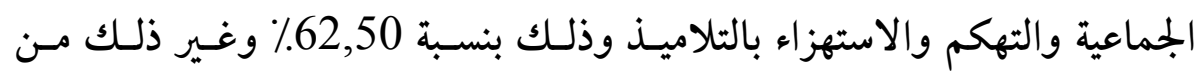
العوامل الموضحة في الجدول. ثالثا- بالنسبة للعوامل الاجتماعية: فقد أكد أفراد العينة على أن الإهمال والنزعة التمات

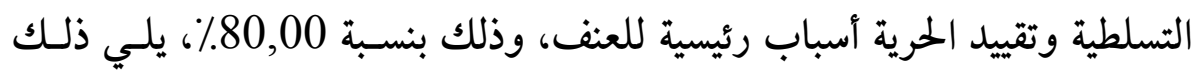

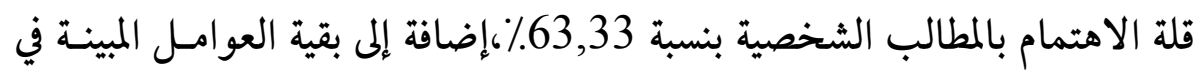

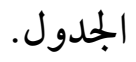

رابعا- بالنسبة للعوامل الثقافية: فقد أكد العديد من أفراد العينة على أن المقالات

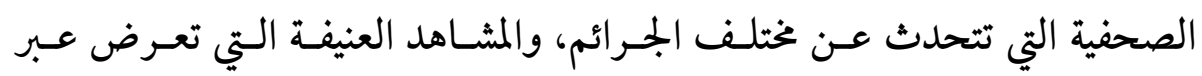


وسائل الإعلام تـدفع للعنـف وذلك بنسـبة 83,33\%، جـاء بعـد ذلـك مشــاهدة

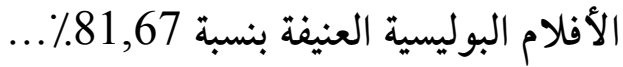

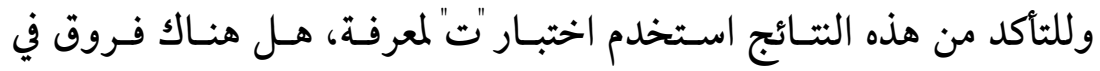

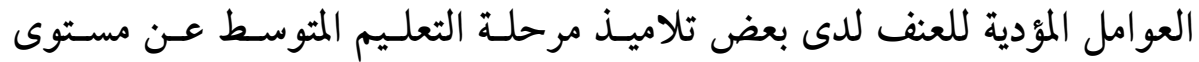

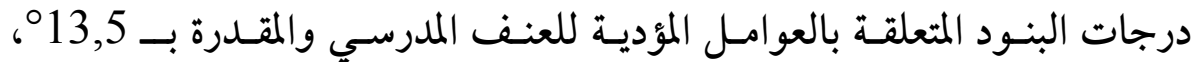
والجدول الآتي يوضح ذلك:

\begin{tabular}{|c|c|c|c|c|c|c|c|c|}
\hline مستوى الدلالة & الحرية & قيمة ت & للمتوسط الذياري & المعياري اف & المعد في & الحسابي & ألعزد & لدرجتات \\
\hline ,000 & 119 & 10,236 & 0,26 & 2,81 & 2,63 & 16,13 & 120 & المؤدية للعنف \\
\hline
\end{tabular}

المتأمل لمعطيات هذا الجدول (7) يتبين له أن منوسط درجات مختلف العو امل المؤدية للعنف المدرسي وصل إلى 16,13، وهو أعلى من مستوى المتوسط المقدر بـ

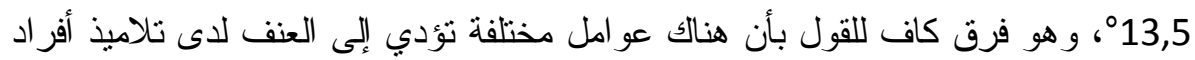

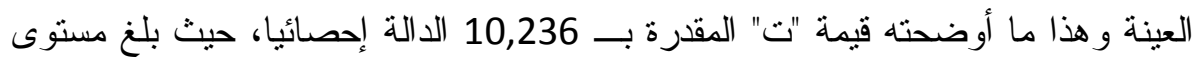
الدلالة المحسوب 0,000، وهو أصغر من مستوى الدلالة المعتمد 0,05 عند مستوى الثقة 95، وهذا يعني أن مسنوى درجات العوامل المؤدية للعنف المدرسي أعلى من المستوى المفروض.

ومما سبق من معطيات الجدولين (6 و7) يمكن القول أن ظاهرة العنف المدرسي

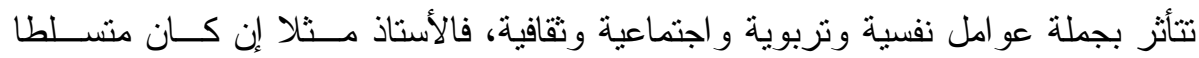
و عاجز ا عن تحقيق تو افقه المهني لا شك أنه يمثل القدوة السيئة لأنه من خلال ســلوكاته

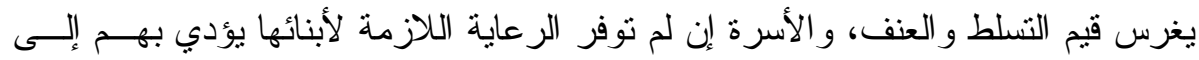

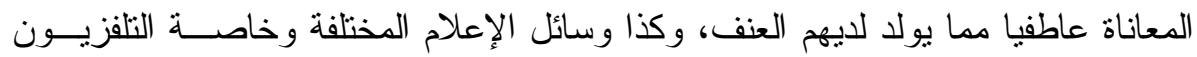

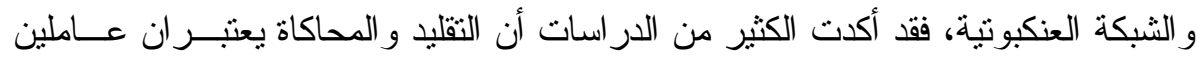
أساسيين لحدوث السلوك العنيف من خلال التقليد لما يشثاهد عبر التلفزيـــون و الانترنــــ، ومنه يمكن التأكيد على وجود عو امل نفسية وتربوية واجتماعية وثقافية متداخلة فيما بينها 
تؤدي إلى ظاهرة العنف المدرسي لدى تلاميذ مرحلة التعليم المتوسط، وعليه فإنه يمكـن

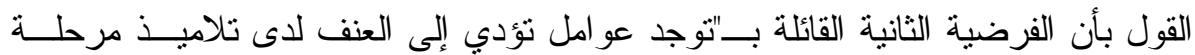
التعليم المنوسط" قد تحققت.

1-2-3: البيانات المتعلقة بلور الأخصائي النفسي في التخفيــف مـن ظـــاهرة العنف المدرسي:

تشمل البيانات المتعلقة بهذا القسم ثلاثة عشر بندا، وهي تتعلق بالفرضــية الثالثــة

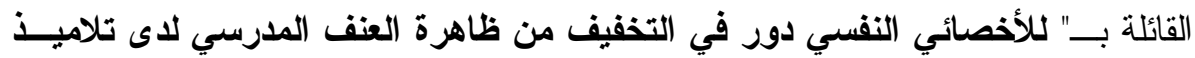

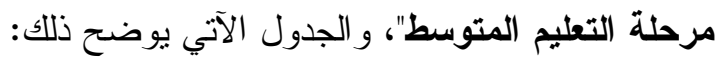
جدول رقم (8) يبين دور الأخصائي النفسي في التخفيف من ظاهرة العنف بحسب التب وجهة نظر أفر اد العينة.

\begin{tabular}{|c|c|c|c|c|c|}
\hline \multicolumn{2}{|c|}{ ע } & \multicolumn{2}{|c|}{ 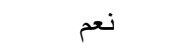 } & \multirow[t]{2}{*}{ 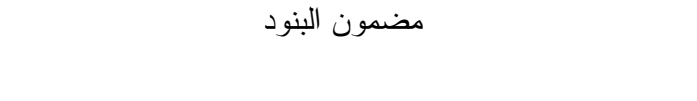 } & \multirow[t]{2}{*}{ 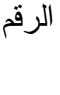 } \\
\hline$\%$ & $ت$ & $\%$ & ت & & \\
\hline 25,00 & 30 & 75,00 & 90 & اكتتاف وتتخيص مشكلات التلاميذ بغية إيجاد حلول لها. & 40 \\
\hline 23,33 & 28 & 76,67 & 92 & اليجاديذ الحلول المنطقية و المعقولة للمشكلات التــي يواجههـــا & 41 \\
\hline 33,33 & 40 & 66,67 & 80 & متابعة النمو النفسي للتناميذ خلا هذه المرحلة. & 42 \\
\hline 35,00 & 42 & 65,00 & 78 & و الأيجاد مناخ نفسي نزداد فيه فرص التفاعـلـل بــين التلاميــذ & 43 \\
\hline 28,33 & 34 & 71,66 & 86 & تحقيق الاتصال المفقود بين المؤسسة التعليمية والأسرة. & 44 \\
\hline 25,00 & 30 & 75,00 & 90 & ومع الزملاءة التلاميذ أصحاب المشكلات على التكيف مع الـــفس & 45 \\
\hline 33,33 & 40 & 66,67 & 80 & تشجيع التلاميذ على المشاركة في مختلف الأنشطة المدرسية. & 46 \\
\hline 08,33 & 10 & 91,67 & 110 & 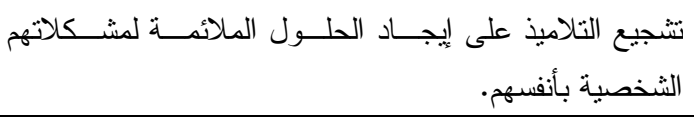 & 47 \\
\hline 16,67 & 20 & 83,33 & 100 & تقديم النصح و المساعدة الفنية للتلاميذ و الأساتذة. & 48 \\
\hline 41,67 & 50 & 58,33 & 70 & إحالة التلاميذ أصحاب المشكلات على المر اكز المتخصصة. & 49 \\
\hline 50,00 & 60 & 50,00 & 60 & تطوير المفهوم الايجابي للذات وبناء النقة بالآخرين. & 50 \\
\hline 35,00 & 42 & 65,00 & 78 & تشجيع التلاميذ على التعبير عن انفعالاتهر ومشاعر هم بهدوء. & 51 \\
\hline
\end{tabular}




\begin{tabular}{|l|l|l|l|l|l|l|}
\hline 18,33 & 22 & 81,67 & 98 & & \\
\hline
\end{tabular}

$$
\text { من خلال هذا الجدول (8) يتضح ما يلي: }
$$

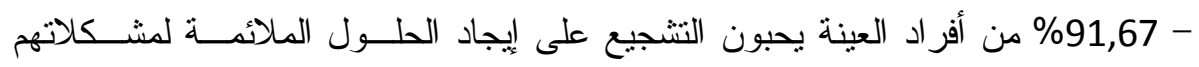
الثخصية بأنفسهم.

- 83,33\% من أفر اد العينة يحبون تقديم النصح و المساعدة الفنية. - 81,67 من أفراد العينة يحبون النتجيع على التو اصل مع الآخرين بشكل هادئ.

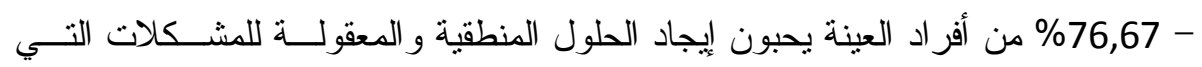

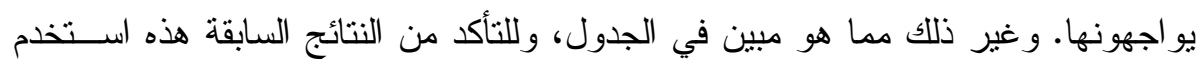

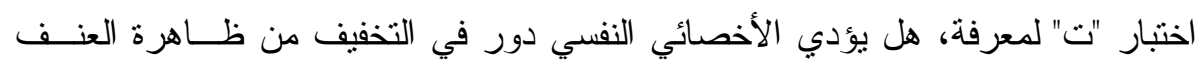
بشكل جوهري عن معدل درجات العنف، و الجدول الآتي يوضح ذللك. جدول رقم (9) يبين المتوسط الحسابي و الانحر اف المعياري لمعدل البنود المتعلقة

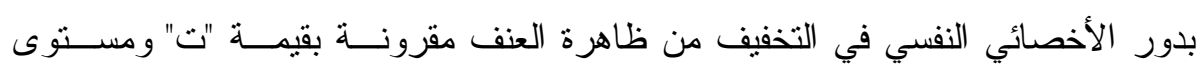

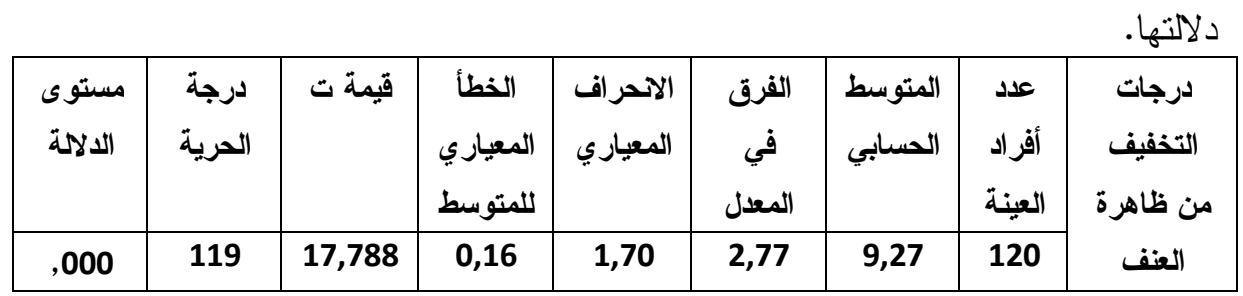

يتضح من هذا الجدول (9) أن متوسط درجات التخفيــف مـن ظـــاهرة العنــف

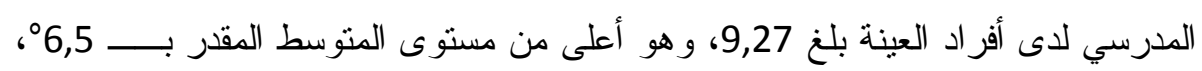

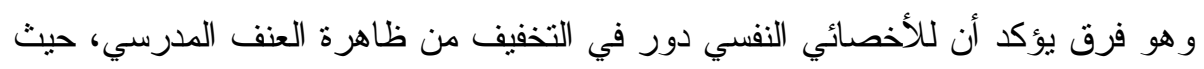

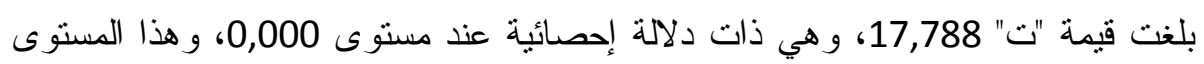

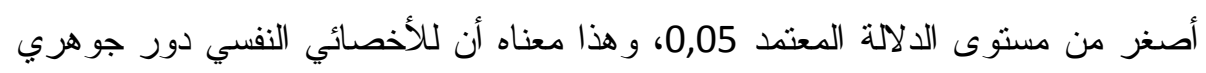
في التخفيف من معدل درجات العنف المدرسي. ومما سبق، ومن خلال معطيات الجدولين (8 و9) يمكـن القــول أن الأخصــائي النفسي في أي مؤسسة تعليمية له دور في غاية الأهمية في مساعدة التلاميذ وخاصة ذوبي 
المشكلات النفسية و التربوية وحتى الاجتماعية في إثنر اكهم في تتخيص مشكلاتهم تلـــك

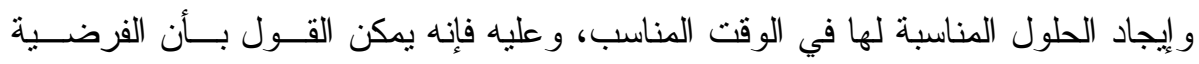

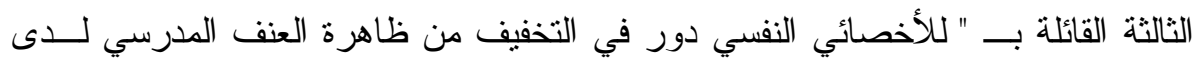
تلامبذ مرحلة التعليم المتوسط"، قد تحققت. 2- مقترحاث الار اسة:

إن ظاهرة العنف لدى تلاميذ مرحلة التعليم المتوسط ظاهرة خطيرة معقدة متعـددة

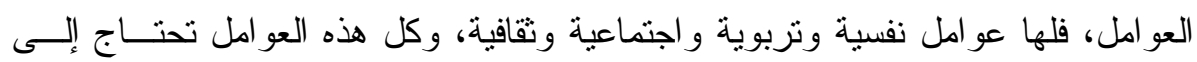

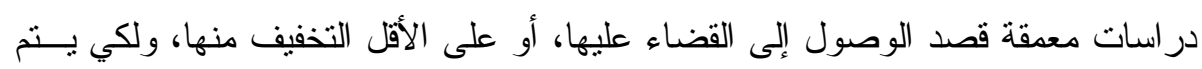
تحقيق ذلك يمكن تقديم المقترحات التالية: 2-1: توجيه الباحثين في مختلف العلوم الإنسانية و الاجتماعية و الدينية و القانونيـــة إلـى در اسة هذه الظاهرة و التعمق في مختلف جو انبها لإعطاء تشخيص دقيق يمكن من اقتر اح البدائل المناسبة لذلك. 2-2-2: القيام بدورات وملتقيات عملية لتكوين المشرفين علــى تربيــة وتعلــيم التناميــذ و إرشادهم إلى طرق وسبل التعامل مع التلاميذ وفق احتياجاتهم و إمكاناتهم. 2-3: العمل على إثناعة ثقافة السلم و اللاعنف من خلال غرس قـيم التســامح و العــدل

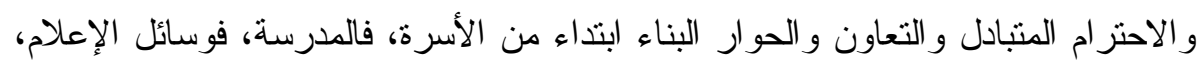
عملا بالقول المأثور "الوقاية خير من العلاج".

2-4: تعيين أخصائي نفسي مدرسي في كل مؤسسة تعليمية، و العمل على تفعيل دوره.

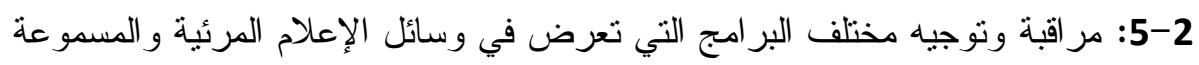
و المكتوبة، ففي ذلك وقاية للتلاميذ في هذه المرحلة من ممارسة العنف. خاتمة:

لقد اتضح من خلال ما سبق أن ظاهرة العنف المدرسي ظاهرة خطيرة، تهدد كيان

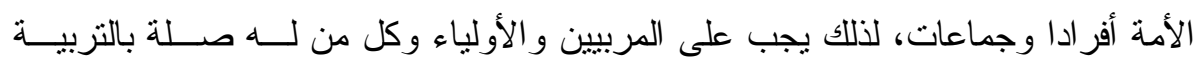
و التعليم التفطن لخطورتها، و العمل سويا لوضع برنامج وقائي علاجي فوري لعلاجها، أو ولوناء 


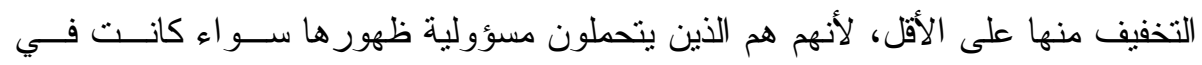
صورة شتم أو سب أو ضربـ... هذا وقد كثفت هذه الدر اسة أن نسبة معتبرة من التلاميذ أفر اد العينة لديهم استعداد

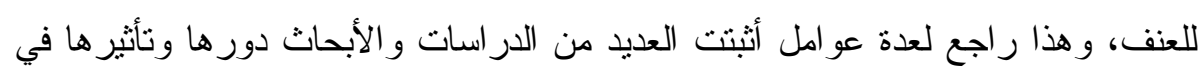

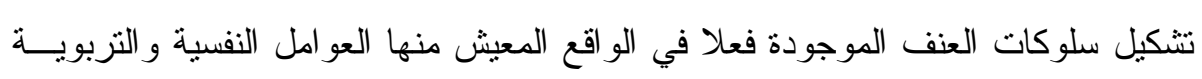

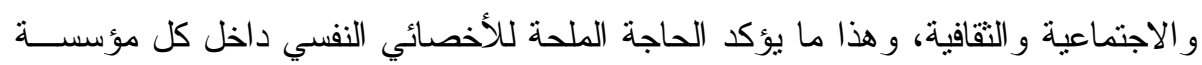

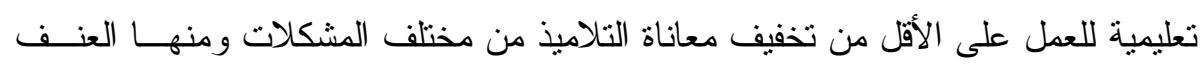
المدرسي. 